\title{
Manganese Accumulation in the Brain via Various Transporters and Its Neurotoxicity Mechanisms
}

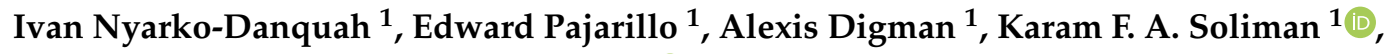 \\ Michael Aschner ${ }^{2,3}$ and Eunsook Lee ${ }^{1, *(\mathbb{D}}$ \\ 1 Division of Pharmaceutical Sciences, Florida A\&M University, Tallahassee, FL 32307, USA; \\ ivan1.nyarkodanquah@famu.edu (I.N.-D.); edward.pajarillo@famu.edu (E.P.); \\ alexis1.digman@famu.edu (A.D.); karam.soliman@famu.edu (K.F.A.S.) \\ 2 Department of Molecular Pharmacology, Albert Einstein College of Medicine Bronx, New York, NY 10461, \\ USA; michael.aschner@einsteinmed.org \\ 3 Laboratory of Molecular Nutrition of the Institute for Personalized Medicine, I. M. Sechenov First Moscow \\ State Medical University, 119146 Moscow, Russia \\ * Correspondence: eunsook.lee@famu.edu; Tel.: +1-(850)-412-7565 \\ Academic Editor: Derek J. McPhee \\ Received: 24 November 2020; Accepted: 9 December 2020; Published: 12 December 2020

\begin{abstract}
Manganese (Mn) is an essential trace element, serving as a cofactor for several key enzymes, such as glutamine synthetase, arginase, pyruvate decarboxylase, and mitochondrial superoxide dismutase. However, its chronic overexposure can result in a neurological disorder referred to as manganism, presenting symptoms similar to those inherent to Parkinson's disease. The pathological symptoms of Mn-induced toxicity are well-known, but the underlying mechanisms of Mn transport to the brain and cellular toxicity leading to Mn's neurotoxicity are not completely understood. Mn's levels in the brain are regulated by multiple transporters responsible for its uptake and efflux, and thus, dysregulation of these transporters may result in Mn accumulation in the brain, causing neurotoxicity. Its distribution and subcellular localization in the brain and associated subcellular toxicity mechanisms have also been extensively studied. This review highlights the presently known Mn transporters and their roles in Mn-induced neurotoxicity, as well as subsequent molecular and cellular dysregulation upon its intracellular uptakes, such as oxidative stress, neuroinflammation, disruption of neurotransmission, $\alpha$-synuclein aggregation, and amyloidogenesis.
\end{abstract}

Keywords: manganese; DMT1; ZIP4; ZIP8; oxidative stress; inflammation; dopamine; acetylcholine; glutamate; GABA; $\alpha$-synuclein

\section{Introduction}

Manganese (Mn) is a trace element in the body, found sufficiently in food [1], and thus, a Mn deficiency-causing pathological condition is rare [2]. Mn plays a critical role in proper bone formation, cell survival, metabolism, and antioxidant defense systems [2]. It serves as an essential cofactor of glutamine synthetase and superoxide dismutase, which are enzymes responsible for the glutamate-glutamine cycle and reactive oxygen species (ROS) scavenging, respectively [3]. Studies have also shown that iron and zinc can be replaced by $\mathrm{Mn}$ as a cofactor for some enzymes, maintaining proper function [4], indicating that, in the absence of iron and zinc, Mn can serve as a cofactor for some enzymes involved in critical biological activities.

Chronic exposure to excess levels of $\mathrm{Mn}$ is, however, a growing health-related concern, as it causes a neurological disorder referred to as manganism, presenting similar pathological symptoms to those of Parkinson's disease (PD), including dopaminergic neuronal injury and motor dysfunction, as well as cognitive deficits [5]. Mn overexposure may result from environmental and/or occupational settings, 
such as mining, smelting, and agrochemical and biomedical industries [6,7]. Mn neurotoxicity is associated with Mn accumulation in various regions of the brain, including basal ganglia, frontal cortex, and cerebellum [8]. Moreover, increasing evidence reveals that Mn may also be a risk factor for several other neurodegenerative disorders, including Alzheimer's disease (AD), dementia, and Huntington's disease (HD), to name a few [9].

The entry of Mn into the body is via the inhalation of fumes, dust, and air particulates, as well as ingestion of contaminated food and water, leading to its subsequent accumulation in the brain. Inhaled Mn is absorbed in the lungs and enters the circulation, while ingested Mn is rapidly absorbed in intestinal epithelial cells via its transporters [10]. Mn levels in the body are regulated by multiple transporters, including transmembrane transporters such as divalent metal transporter 1 (DMT1) [11], transferrin and transferrin receptor (TR) [12], zinc-interacting proteins (ZIP8 and ZIP14) [13,14], calcium channels [15], citrate transporters [16], ferroportin (Fpn) [17], and SLC30A10 [18], as well as the intracellular trafficking proteins (SPCA1 and ATP13A2). Dysregulation of these transporters may lead to Mn accumulation in the brain, causing Mn-induced neurotoxicity [19].

The pathological consequences of Mn toxicity upon its accumulation in the brain are extensively investigated, but the molecular and cellular mechanisms underlying its detrimental effects remain poorly understood. Mn induces oxidative stress by the overproduction of reactive oxygen species (ROS) and neuroinflammation by elevating proinflammatory cytokines in various in vitro and in vivo animal models, indicating that oxidative stress and inflammation are critically involved in Mn-induced neurotoxicity [20-23]. Mn dysregulates multiple neurotransmitters, including dopamine (DA), glutamate, gamma aminobutyric acid (GABA), and acetylcholine (ACh) [24-27], indicating that Mn toxicity could affect multiple brain functions associated with these neurotransmission imbalances, such as motor deficits, learning, memory, and cognition. Although the direct link between Mn toxicity and PD-related Lewy bodies remains to be established, studies have shown that Mn dysregulated the function of $\alpha$-synuclein ( $\alpha$ Syn), a protein commonly found in Lewy bodies in the brain of PD patients [28]. Growing evidence also suggests that $\mathrm{Mn}$ is associated with AD via the overproduction and aggregation of amyloid- $\beta(\mathrm{A} \beta)$, one of $\mathrm{AD}^{\prime}$ s pathological hallmarks.

This review will focus on each Mn transporter's contributing role in Mn accumulation in the brain and delineating the molecular and cellular mechanisms of Mn-induced neurotoxicity, particularly oxidative stress, inflammation, and aberrant neurotransmitter systems. Moreover, Mn's potential contributing role to $\alpha$ Syn aggregation in $\mathrm{PD}$ and $\mathrm{A} \beta$ accumulation in AD will also be discussed.

\section{Mn Transport to the Brain}

Mn can be transported in and out of the brain by its transporters [9]. Multiple transporters for Mn have been identified, although the significant role of each of these transporters in Mn's neurotoxicity is still under investigation $[9,29,30]$.

Several carrier proteins are involved in Mn's transport across the blood-brain barrier (BBB). Mn is transported into the brain via several importers, including DMT1, zinc-interacting protein 8 (ZIP8, encoded by SLC39A8) and ZIP14 (SLC39A14), transferrin and TR, citrate transporter, and calcium channels. $\mathrm{Mn}$ is transported into the brain either as $\mathrm{Mn}^{2+}, \mathrm{Mn}$-citrate, or $\mathrm{Mn}^{3+}$-transferrin. All the transport mechanisms known to date play a part in delivering Mn to the brain, and it is unlikely that $\mathrm{Mn}$ influx across the BBB can be attributed to a single carrier.

\subsection{DMT1}

DMT1 belongs to the family of natural resistance-associated macrophage proteins (NRAMP) [31,32], which was identified as a homolog of NRAMP1, a protein involved in the host defense against several types of infections [33,34]. It is highly expressed in the plasma membrane and endosome [35], as well as the mitochondria of various animal cells [36,37], playing a role in mitochondrial iron and Mn acquisition [11]. Mutation of this gene in humans is associated with severe congenital hypochromic microcytic anemia and an iron overload [38,39]. While DMT1 is ubiquitously expressed, most notably 
in the proximal duodenum in the peripheral tissues [31,40,41], it is highly expressed in basal ganglia, including the caudate nucleus, the putamen, and the substantia nigra, which could explain the sensitivity of this region of the brain to Mn toxicity [42]. DMT1 is also known to be expressed in glial cells in the neocortex, subcortical white matter, and hippocampus [43].

Mn exposure in vivo induced DMT1 expression in the brain subventricular zone and the rostral migratory stream, and this may have partly contributed to Mn overload in the subventricular zone in association with Mn-induced aberrant adult neurogenesis [44]. Olfactory DMT1 also appeared to play a critical role in Mn uptake into the brain, as the nasal absorption of $\mathrm{Mn}$ is significantly reduced in DMT1-mutated $b / b$ rats [45] and an iron deficiency increased the olfactory DMT1 levels, suggesting the importance of olfactory DMT1 in Mn transport to the brain and its modulation by the iron status [45]. Other studies showed that Mn crossed the BBB into the brain by DMT1-independent processes [46], indicating various transporters with different routes for Mn transport into the brain. Single nucleotide polymorphisms (SNPs) in DMT1 are associated with an increased incidence of PD [47,48]; however, whether these SNPs enhance Mn deposition, implying gain-of-function in transporters, has yet to be determined.

\subsection{ZIP8 and ZIP14}

ZIP8 is a transmembrane protein encoded by the SLC39A8 gene and expressed on the apical surface of brain capillaries, shuttling various divalent ions under normal biological conditions [49], including Mn transport to the brain [13]. ZIP8 is abundantly expressed in lung tissues in humans [50,51], and the alveolar epithelia of the lungs provide an entry route for inhaled $\mathrm{Mn}$, indicating its important role in Mn transport into the body via lung tissues [52]. ZIP8 in the brain microvascular capillary endothelial cells also plays a critical role in Mn uptake into the brain [53]. ZIP8 expression is enriched at the apical side of human choroid plexus papilloma cells, which are related to the blood-cerebrospinal fluid (CSF) barrier, contributing to Mn accumulation in these cells [54]. These findings suggest that ZIP8 transporter is important in Mn transport into the brain.

ZIP14, encoded by the SLC39A14 gene, mediates the cellular uptake of Mn, zinc, and iron [14,55] and is highly expressed in the liver, kidney, and testis [56,57]. ZIP14 appears to prevent Mn accumulation in the brain. Mutations in this gene lead to an excessive accumulation of Mn in the brain, resulting in rapidly progressive childhood-onset parkinsonism [58]. The deletion of ZIP14-impaired Mn uptake by the liver and pancreas in Slc39a14 ${ }^{-/}$mice results in a reduction of gastrointestinal excretion of Mn and a subsequent Mn accumulation in the body, most notably in the bone and brain [59]. A zebrafish model lacking ZIP14 accumulated higher Mn levels in the brain compared to those in wild-type (WT), leading to altered locomotor activity [58]. ZIP14 is enriched on the basolateral side of choroid plexus cells, contributing to Mn transport through these cells and the subsequent excretion [54]. ZIP14 mutation caused Mn accumulation in early-onset parkinsonism dystonia patients, suggesting the important role of ZIP14 in the regulation of Mn levels in the brain to prevent Mn neurotoxicity in humans [58]. Studies also showed that Mn levels were elevated in the CSF of patients carrying an SLC39A14 mutation, supporting the role of ZIP14 in lowering Mn levels in the brain [60].

\subsection{Transferrin and Transferrin Receptor (TR)}

Transferrin primarily mediates iron transport in blood circulation, but it can also transport Mn (mostly $\mathrm{Mn}^{3+}$ ) into the brain $[16,61,62]$. The TR, expressed in neurons, microglia, or astrocytes, binds and uptakes the Mn-transferrin complex into the cells [63,64]. The significance of the transferrin/TR-mediated transport of $\mathrm{Mn}$ to the brain remains unclear, since mice with low plasma transferrin levels could maintain normal brain Mn contents [12].

\subsection{Citrate Transporter and Calcium Channels}

Mn-citrate is believed to be the major form to transport Mn to the brain, as Mn-citrate has been reported as the most abundant Mn species found in Mn carriers in serum [65]. Mn-citrate crosses the 
BBB in a citrate transporter-dependent mechanism [16]. The monocarboxylate transporter and the organic anion transporter are also putative carriers for Mn-citrate into the brain [66]. However, the role of citrate in Mn transport via a specific type of citrate carrier in Mn accumulation in the brain remains to be established.

Mn also enters the brain through ligand-gated store-operated calcium channels, which are expressed in brain endothelial cells [15], as well as voltage-gated L-type calcium channels in dopaminergic neurons of the midbrain, which could contribute to the selective vulnerability of these neurons to Mn toxicity [67].

\subsection{Fpn}

Fpn is a transmembrane protein expressed in the plasma membrane and known to export intracellular iron in mammals [68,69]. It also exports intracellular Mn into the extracellular space, thus playing a protective role in Mn-induced cellular toxicity and oxidative stress [17]. Fpn is expressed in various brain cell types, including neurons, astrocytes, the BBB endothelial cells, oligodendrocytes, choroid plexus, and ependymal cells [70]. Fpn overexpression reduced Mn accumulation, resulting in attenuating Mn-induced cytotoxicity in the mouse brain [71], suggesting that Fpn plays an important role in regulating Mn levels in the brain.

\subsection{SLC $30 A 10$}

SLC30A10 is one of the 10 solute carrier family 30 (SLC30) transporters. Unlike the majority of the members in this family, which mediate zinc transport, the SLC30A10 transporter mediates Mn efflux [18,72], thus protecting against Mn-induced cellular toxicity. Mutation of the SLC30A10 gene causes Mn overload syndrome, resulting in parkinsonism with hypermanganesemia [73,74]. It is currently the only known transporter associated with the familial form of Mn-induced parkinsonism [75]. The liver and gastrointestinal tract-specific Slc30a10 knockout mice induced a marked elevation of Mn levels in the brain, suggesting that the damage that results from brain $\mathrm{Mn}$ is regulated by the activity of SLC30A10 in the liver and gastrointestinal tract [76].

\subsection{Intracellular Mn Distribution and Storage}

In addition to the plasma membrane transporters, some transporters expressed in the membranes of intracellular organelles regulate subcellular Mn transport and distribution. Studies suggest that lysosomes, the Golgi apparatus, endosomes, mitochondria, and the nucleus, are subcellular organelles for the accumulation of intracellular Mn [77-79].

The calcium uniporter sequesters intracellular $\mathrm{Mn}^{2+}$ in the mitochondria [80]. Since $\mathrm{Mn}^{2+}$ can be oxidized to a strong pro-oxidizing agent, $\mathrm{Mn}^{3+}$, by superoxide [81] and the mitochondrial electron transport chain, is the largest producer of superoxide in the cell [82]; it is believed that the oxidation of $\mathrm{Mn}^{2+}$ to $\mathrm{Mn}^{3+}$ damages mitochondria [81].

The transferrin/TR transports Mn into endosomes and mitochondria in mouse hippocampal and striatal neuronal cells [62], although DMT1 is also expressed in the endosomes, transporting Mn into the cytoplasm [62].

PARK9 (encoded by ATP13A2) is a P-type ATPase of unknown function [83], but mutations in the ATP13A2 gene are associated with Kufor-Rakeb syndrome and are found also in patients with various other types of parkinsonism, causing an autosomal recessive parkinsonian syndrome [84]. Mutations in this gene also cause a syndrome of neurodegeneration with brain iron accumulation (NBIA), which is characterized by an abnormal accumulation of iron in the basal ganglia [85]. PARK9 is localized predominantly in lysosomes and is involved in the shuttling of cations across the membrane of the lysosome [84], helping sequester toxic metals such as Mn. PARK9 is highly expressed in the neurons of the substantia nigra, protecting neurons against Mn-induced neurotoxicity $[83,84,86]$, suggesting its important role in protecting cells against Mn cytotoxicity via regulating intracellular Mn redistribution into vacuoles. 
SPCA1 is a Ca/Mn ATPase expressed highly on the surface of the Golgi membrane, transporting Mn and calcium from the cytosol into the Golgi lumen [87,88]. This allows for the safe storage of calcium and export of excess Mn via the secretory pathway. The role of SPCA1 in Mn transport is important to maintain optimal Mn level, since its silencing or deficiency results in extreme sensitivity to Mn toxicity $[89,90]$.

\section{Mechanisms of Mn-Induced Neurotoxicity}

Excessive Mn levels alter cellular functions by multiple mechanisms. In the brain, Mn can directly cause neuronal toxicity by the inhibition of mitochondrial respiration, leading to energy failure, oxidative stress [91], and excitotoxicity [92]. Mn can also induce neurotoxicity by impairing functions of glial cells such as astrocytes and microglia. Moreover, Mn toxicity continues to progress even after cessation of its exposure, suggesting that there are ongoing mechanisms of progression for Mn toxicity, such as inflammation and protein aggregation [2,93]. Here, we will focus on the mechanisms of Mn neurotoxicity, including oxidative stress, neuroinflammation, neurotransmitter dysregulation, and $\alpha$ Syn aggregation in various in vitro and in vivo experimental settings (Table 1 ).

\subsection{Oxidative Stress}

Oxidative stress is one of the major mechanisms of Mn-induced neurotoxicity. Mn accumulation in the brain exacerbates oxidative damage preferentially in the basal ganglia, including the globus pallidus and striatum. These regions are especially vulnerable to oxidative injury due to their intense oxygen consumption reflective of a high metabolic rate and significant DA content. Mn-increased ROS production leads to the activation of proapoptotic processes such as cytochrome $c$ release from the mitochondria, activation of caspase-3, and DNA fragmentation in dopaminergic cell lines [94]. Mn-induced ROS-triggered mitochondria-dependent apoptotic activation was independent of caspase-8 [95] but dependent on protein kinase C delta (PKC 8 ) [95,96]. The antioxidant Trolox attenuated $\mathrm{Mn}$-induced neurotoxicity and rescued dysfunctional dopaminergic transmission and Mn-induced motor coordination deficits in both in vitro and in vivo experimental settings [21,22], indicating that oxidative stress is a critical mechanism of Mn-induced neurotoxicity.

In addition, Mn could exacerbate DA-induced oxidative damage in dopaminergic neurons, since DA itself can undergo oxidation to produce quinones and free radicals that can be neurotoxic and contribute to neurodegenerative processes in cells [97], as well as Caenorhabditis elegans [98]. The process of DA metabolism to homovanillic acid by monoamine oxidase and catechol-O-methyltransferase can also produce $\mathrm{H}_{2} \mathrm{O}_{2}$, leading to oxidative stress in the nigrostriatal system.

Mn-induced impairment of the neuronal antioxidant system renders the brain more susceptible to Mn toxicity, contributing to altered striatal concentrations of glutathione, glutathione disulfide, ascorbic acid, malondialdehyde, and the activities of glutathione reductase and glutathione peroxidase [99-101]. Impairment of the antioxidant system may also play a role in developing neurodegenerative diseases by shifting the balance between the generation of ROS and its elimination. Glutathione provides the first-line endogenous agent of cellular defense against oxidative stress in both neurons and astrocytes. The inhibition of glutathione synthesis potentiates Mn-induced energetic impairment by increasing the hypoxanthine, xanthine, and uric acid levels in the striatum and brainstems of aged rats [102], implicating that mitochondrial dysfunction is closely associated with the Mn-induced impairment of antioxidant functions.

Mn-induced ROS also oxidizes polyunsaturated fatty acids present in the cell membrane, leading to the production of several arachidonic acid peroxidation products, such as F2-isoprostanes, which is considered the most accurate measure of oxidative damage [103-105], increasing F2-isoprostanes levels leading to cellular damage in both primary neurons and astrocytes $[106,107]$.

Oxidative stress can also damage cellular macromolecules such as nucleic acids, which are prone to irreparable damage from oxidative damage, since any form of oxidative modification can lead to genetic base mutations. Higher levels of the oxidized DNA product 8-hydroxyguanosine, 
as well as reduced 8-hydroxyl-2-deoxyguanosine, have been observed in the substantia nigra and CSF of PD patients [108,109], suggesting that oxidative stress leads to the oxidation of nucleobases. Importantly, Mn induced oxidative damage to thymine DNA bases in SH-SY5Y cells [23]. Taken together, these findings indicate that Mn-induced ROS production contributes to oxidative damage in DNA molecules and the subsequent genetic base mutations.

\subsection{Inflammation}

Glial cells, including astrocytes and microglia, represent a diverse class of cells in the brain, making up $50 \%$ of all cells in the central nervous system. The involvement of glia in Mn-induced neurotoxicity has received significant attention [93], since Mn activated glial cells in the brains of humans, nonhuman primates, and rodents [21,110-112], exerting lasting effects on the neuroinflammatory status of glial cells [113]. Activated astrocytes and microglia are often observed in the postmortem evaluation of Mn-exposed patients [112].

Astrocytes are well-established to play a critical role in Mn-induced neuroinflammation, as Mn accumulates preferentially in this cell type in the brain [114], potentially due to the abundant expression of high-capacity transporters [115]. In addition to DMT1 [7], the TRs expressed on astrocytic surfaces readily bind to Mn-transferrin, allowing them to retain Mn concentrations 10to 50-fold greater than those in neurons and, thus, are more susceptible to Mn toxicity than other cell types [116]. Mn significantly increased astrogliosis in the basal ganglia of patients exposed to high Mn levels [117]. Mn released cytotoxic substances such as iNOS and IL-6 [118] and increased mRNA levels of various inflammatory genes in astrocytes [119]. Mn increased the expression of cyclooxygenase 2 and iNOS by the activation of NF- $\mathrm{KB}$ in astrocytes, leading to inflammation and neuronal apoptosis [118,120-122], suggesting that astrocytes could play an important role in Mn-induced neuroinflammation. Mn in low levels also potentiated lipopolysaccharide (LPS)-induced inflammation of glial cells and enhanced neurotoxicity [123] in astrocytes by increasing the production of TNF- $\alpha$, IL-1 $\beta$, and iNOS expression [20,118,124-126].

Microglia, another glial cell type acting as the major immune cells in the brain, play a critical role in Mn-induced neurotoxicity by producing proinflammatory cytokines [125], which can be exacerbated indirectly by Mn-stimulated astrocytes [127], leading to neuronal injury. Mn also induced the release of microglial-derived cytokines such as TNF- $\alpha$, ILs, and interferons by activation of the NF- $\mathrm{B}$ pathway in microglia $[93,125,128]$. Mn at low concentrations potentiated the LPS-induced microglial release of cytokines such as TNF- $\alpha$ and IL-1 $\beta[125,127]$. The potentiating effect of Mn on TNF- $\alpha$ and IL-6 at the mRNA level was delayed but sustained for up to $24 \mathrm{~h}[129,130]$. In our previous study, leucine-rich repeat kinase 2 (LRRK2) appears to mediate Mn-induced inflammation, since Mn increased the expression of LRRK2 and its kinase activity in microglia, leading to the enhancement of cytokine production such as TNF- $\alpha$, but the genetic deletion or pharmacological inhibition of LRRK2 attenuated Mn-induced cytotoxicity in microglial cells [131].

\subsection{Mn Effect on Neurotransmitters}

Mn could interfere with multiple neurotransmission systems as it accumulates in various brain regions, comprising an intricate network of neurons that synthesize and release multiple neurotransmitters, including DA, glutamate, ACh, and GABA. In fact, Mn has been shown to dysregulate these neurotransmission systems.

DA. Mn accumulation in the basal ganglia decreased DA levels in neonates [132], as well as adult rats [133], particularly in the dopaminergic neurons of the substantia nigra pars compacta, where dopaminergic cell bodies are located [77]. In addition, Mn also decreased the levels of DA and its turnover [134], depleted DA stores, and decreased DA release [135] in the striatum of rats, resulting in reduced dopaminergic neurotransmission, along with behavioral deficits, in rats [136]. In humans, the expression of a dopamine transporter was decreased in Mn-exposed patients [27], leading to the dysregulation of dopaminergic neurotransmissions [137]. We have previously reported 
that $\mathrm{Mn}$ induced dopaminergic neuronal injury and decreased the expression of tyrosine hydroxylase (TH) in the mouse brain [138-140]. Mn also increased the phosphorylation of TH at the serine 40 residue post-translationally and caused oxidative stress and apoptosis in PC12 cells [141]. We have found that Mn decreased TH mRNA and protein levels at the transcriptional level by decreasing the transcription factor repressor element-1 silencing transcription factor (REST) in dopaminergic cells [139]. The overexpression of REST increased its binding to the cis element of REST in the human TH promoter and interacted with histone acetyltransferase CREB-binding protein (CBP) to increase the TH expression [139]. REST also protected dopaminergic cells against Mn-induced neurotoxicity by enhancing its antioxidant and antiapoptotic proteins. The protective role of REST appears critical in Mn-induced dopaminergic neurotoxicity, as well as other neurodegenerative diseases, including PD [142] and AD [143]. Studies also showed that Mn impaired the TH activity via the activation of protein kinase $\mathrm{C} \delta$ and protein phosphatase 2A in dopaminergic cells [144]. These findings suggest that Mn impairs TH function by various mechanisms and promotes dopaminergic neuronal injury, leading to aberrant DA neurotransmission.

Glutamate. Mn dysregulates glutamate neurotransmission in the brain by impairing glutamate transporters and the N-methyl-D-aspartate (NMDA) receptor, leading to the overstimulation of postsynaptic glutamate receptors and excitotoxic neuronal death [145]. Studies have reported that Mn overexposure can lead to glutamate-induced excitotoxicity, as the inhibition of the NMDA receptor attenuated excitotoxic lesions in the striatum of Mn-exposed rats [146]. Mn impaired the NMDA receptor function by reducing the mRNA and protein levels of NMDA receptor subunits [147] and dysregulating phosphorylation of the NMDA receptor [148], suggesting that Mn modulate the NMDA receptor function at multiple levels involving transcription, translation, and posttranslational modifications. The Mn-induced dysregulation of the TrkB/Akt/Fyn-mediated phosphorylation of NMDA receptors was associated with the impairment of spatial memory and synaptic plasticity in mice [148]. In addition, Mn-induced glutamate dyshomeostasis could be associated with glutamate transporter dysfunction. We have previously reported that Mn decreased the glutamate uptake in astrocytes, along with a reduced expression of glutamate aspartate transporter 1 (GLAST) and glutamate transporter 1 (GLT-1), resulting in excess extracellular glutamate levels $[8,149,150]$. Since GLAST and GLT-1 are predominantly expressed in astrocytes and responsible for $>90 \%$ of the glutamate uptake from the extracellular space in the brain [145], this Mn-reduced GLT-1/GLAST could directly contribute to excitotoxic neuronal injury. We have found that the Mn-decreased expression of GLT-1/GLAST was at the transcriptional level. The Mn-induced activation of the transcription factor Yin Yang 1 (YY1) was responsible for repressing GLAST and GLT-1 expression in both in vitro astrocyte cultures and in vivo mouse models $[8,149,150]$. Mn also modulated epigenetic modifier histone deacetylases (HDAC) to repress GLAST and GLT-1 expression by increasing the interaction of HDAC with YY1 and the subsequent histone deacetylation in astrocytes $[149,150]$. Astrocytic YY1 was critical in Mn-induced neurotoxicity, since astrocytic YY1 deletion attenuated the Mn-induced repression of GLAST and GLT-1 in the substantia nigra, concomitantly decreasing the interaction between YY1 and HDACs in astrocytes [8]. These findings indicate that Mn promotes neuronal injury by dysregulating the glutamate signal at least in part by the dysregulation of glutamate transporters GLT-1/GLAST and the NMDA receptor.

ACh. Although most relevant mechanisms for Mn neurotoxicity have been related to the brain dopaminergic systems [151], some features of manganism such as intellectual decline [152] cannot be explained by the disruption of brain dopaminergic systems alone. Mn effects on the cholinergic system may also contribute to the impairment in learning, memory, and locomotion [24]. Mn's toxic effects have been suggested to be linked to an imbalance between the dopaminergic and cholinergic systems in the basal ganglia [153]. Studies have shown that Mn inhibited acetylcholinesterase (AChE), resulting in an increase in the production of ROS and reactive nitrogen species, leading to the intracellular accumulation of calcium in the rat brain [154]. Mn also decreased the activity of choline acetyltransferase (ChAT), thus reducing the production of ACh in striatal cholinergic terminals [155]. These Mn effects are 
more pronounced in developing brains, as the expression of ChAT is lower particularly in the midbrain and cerebellum of rats [156]. Mn inhibited the choline transporter, decreasing the choline uptake into cholinergic neurons in the hippocampus, cortex, and basal ganglia [157]. Mn also inhibited ACh binding to its receptors and decreased the expression of nicotinic acetylcholine receptors in the prefrontal cortex of mice, resulting in an impairment of spatial memory [158]. These various findings suggest that Mn could modulate the cholinergic system differently, depending on the experimental settings.

GABA. Mn accumulates primarily in the globus pallidal GABAergic neurons of the basal ganglia, but the effects of Mn on GABAergic neurotransmission are inconsistent. Studies have shown that Mn dysregulated GABA neurotransmission by reducing GABA levels, leading to increased susceptibility to seizures in rats [25]. Mn also inhibited GABA uptake in the rat forebrain [159] and decreased GABA transporter 1 expression in the substantia nigra of rats, resulting in an increase of extracellular GABA concentrations [160]. In humans, Mn-exposed smelters showed that GABA levels were significantly increased in the thalamus and adjacent brain regions, but globus pallidus, which had the most Mn deposition, did not exert the highest alteration of GABA levels [161], suggesting that Mn neurotoxicity may result from the intrinsic vulnerability of neuronal systems to injury rather than the accumulated Mn levels in those local regions of the brain [162]. These findings indicate that Mn effects on GABAergic systems also vary depending on the experimental settings and conditions, requiring further studies to better understand how Mn modulates GABA neurotransmission.

\section{4. $\alpha$ Syn Aggregation}

$\alpha$ Syn, encoded by SNCA, is a major aggregate of Lewy body deposits in the brain of PD patients, and mutations in the SNCA are directly linked to the onset of PD [163]. $\alpha$ Syn appears to confer both neurotoxic and neuroprotective effects in PD experimental models, indicating that the role of $\alpha$ Syn in PD needs to be carefully interpreted.

Studies have shown that the overexpression of $\alpha$ Syn exerted protective effects in dopaminergic cells against Mn-induced neurotoxicity in the short time of Mn exposure, while prolonged Mn exposure abolished $\alpha$ Syn's neuroprotection against Mn toxicity and promoted $\alpha$ Syn aggregation [94], suggesting that the pathogenic mechanism of Mn involves $\alpha$ Syn misfolding. In C. elegans with mutations in $p d r 1$ and djr1.1, homologs of parkin and DJ-1 in humans, the overexpression of $\alpha$ Syn also attenuated Mn accumulation and oxidative stress [164].

Growing evidence also indicates the role of $\alpha$ Syn in Mn neurotoxicity, as Mn increased $\alpha \mathrm{Syn}$ expression, aggregation, and subsequent cytotoxicity in different experimental models [86,165-167]. $\alpha$ Syn is involved in Mn-induced neurotoxicity by $\alpha$ Syn oligomerization and impaired autophagy in mice [168]. Mn increased the expression and aggregation of $\alpha \mathrm{Syn}$, leading to apoptosis in neuronal cells [28], while the knockdown of $\alpha$ Syn with antisense $\alpha$ Syn treatment [169] or siRNA [28] attenuated Mn-induced cytotoxicity, indicating that $\alpha$ Syn was critically involved in Mn-induced cytotoxicity. Mn induced conformational changes and the fibril formation of $\alpha$ Syn, leading to $\alpha$ Syn aggregation in an $\alpha$ Syn peptide solution [170]. Studies also revealed that Mn modulated other mechanisms such as the secretion and vesicular trafficking of $\alpha$ Syn between cells by increasing levels of RAB27A for the packaging of $\alpha$ Syn into exosomes [171], which, in turn, leads to the release of exosomes into the extracellular environment [172]. Serum samples collected from welders chronically exposed to Mn showed increased levels of misfolded $\alpha$ Syn in their exosomes, which have been shown to induce neuroinflammation and subsequent neurodegeneration [173]. 
Table 1. The molecular mechanisms involved in manganese (Mn)-induced toxicity in various neural cell types such as microglia, astrocytes, and neurons and in multiple regions of the brain.

\begin{tabular}{|c|c|c|c|c|c|}
\hline Experimental Model & Species & Mn (Dosage/Concentration) & Cytotoxicity Mechanisms & Disease Model & References \\
\hline \multicolumn{6}{|l|}{ Neural cell type } \\
\hline Microglia & Mouse (N9), Mouse (BV2) & $\mathrm{MnCl}_{2}(50-1000 \mu \mathrm{M})$ & $\uparrow \mathrm{TNF}-\alpha, \uparrow \mathrm{ILs}, \uparrow$ interferons $\uparrow$ NF- $\mathrm{kB}$ activation & Mn toxicity & {$[93,125,128]$} \\
\hline Microglia & Mouse (N9), Rat & $\mathrm{MnCl}_{2}(30 \mu \mathrm{M})$ & $\uparrow \mathrm{TNF}-\alpha, \uparrow \mathrm{IL}-1 \beta$ & Mn toxicity & {$[125,127]$} \\
\hline Microglia & Human (HMC3) & $\mathrm{MnCl}_{2}(250 \mu \mathrm{M})$ & $\begin{array}{c}\text { 个LRRK2 expression and kinase activity } \\
\uparrow R O S, \uparrow T N F-\alpha, \uparrow \text { apoptosis }\end{array}$ & Mn toxicity & [131] \\
\hline Astrocytes & Mice & $\mathrm{MnCl}_{2}(0.1-10 \mu \mathrm{M})$ & $\begin{array}{c}\uparrow \text { Cyclooxygenase } 2, \uparrow \mathrm{iNOS}, \uparrow N F-\kappa \mathrm{B} \text { activation, } \\
\text { †inflammation }\end{array}$ & Mn toxicity & {$[118,120-122]$} \\
\hline Astrocytes & Mouse & $\mathrm{MnCl}_{2}(50 \mu \mathrm{M})$ & $\uparrow$ Inflammation, $\uparrow \mathrm{iNOS}, \uparrow \mathrm{NO}$ & Mn toxicity & [123] \\
\hline Astrocytes & Rat, Mice & $\mathrm{MnCl}_{2}(5,50 \mu \mathrm{M})$ & $\uparrow T N F-\alpha, \uparrow I L-1 \beta, \uparrow$ iNOS & Mn toxicity & {$[20,118,124-126$} \\
\hline Astrocytes & Rat, Human & $\mathrm{MnCl}_{2}(250 \mu \mathrm{M})$ & $\begin{array}{c}\downarrow \text { Glutamate reuptake, } \downarrow \text { EAAT1/GLAST, } \\
\downarrow \text { EAAT2/GLT-1, } \uparrow Y Y 1, \uparrow \text { HDAC-YY1 interaction }\end{array}$ & Mn toxicity & {$[149,150]$} \\
\hline Astrocytes & Rat & $\mathrm{MnCl}_{2}(100-200 \mu \mathrm{M})$ & $\begin{array}{c}\downarrow \text { Glutamate reuptake, } \downarrow \text { SOD activity, } \downarrow \text { GPx activity, } \\
\uparrow \text { LDH release, } \uparrow I L-6\end{array}$ & Mn toxicity & [99] \\
\hline Astrocytes & Rat & $\mathrm{MnCl}_{2}(100,500,1000 \mu \mathrm{M})$ & $\uparrow$ F2-isoprostanes, $\uparrow$ lipid peroxidation & Mn toxicity & [107] \\
\hline Astrocytes & Human (U87) & $\mathrm{MnCl}_{2}(400,800,2000 \mu \mathrm{M})$ & $\downarrow$ Glutathione & Mn toxicity & [100] \\
\hline \multicolumn{6}{|l|}{ Neurons } \\
\hline Cortical Neuron & rat & $\mathrm{MnCl}_{2}(500 \mu \mathrm{M})$ & $\begin{array}{l}\uparrow R O S \text { production, } \uparrow F 2 \text {-isoprostanes, } \downarrow \text { ATP } \\
\text { production }\end{array}$ & Mn toxicity & [22] \\
\hline Dopaminergic & Human (SH-SY5Y) & $\mathrm{MnCl}_{2}(800 \mu \mathrm{M})$ & $\begin{array}{c}\uparrow \text { ROS production, } \uparrow \text { lipid peroxidation, } \downarrow \text { ATP levels, } \\
\downarrow \text { mitochondrial membrane potential }\end{array}$ & Mn toxicity; PD & [101] \\
\hline Dopaminergic & Human (SH-SY5Y) & $\mathrm{MnCl}_{2}(2-125 \mu \mathrm{M})$ & $\uparrow$ DNA damage, $\uparrow$ oxidative stress & Mn toxicity; PD & [23] \\
\hline Dopaminergic & Rat (N27) & $\mathrm{MnCl}_{2}(300 \mu \mathrm{M})$ & $\begin{array}{c}\uparrow \text { Cytochrome c release, } \uparrow \text { caspase- } 3 \text { activation, } \uparrow \text { DNA } \\
\text { damage, } \uparrow \text { ROS, } \uparrow \text { apoptosis, } \uparrow \alpha \text { Syn aggregation }\end{array}$ & Mn toxicity & [94] \\
\hline Dopaminergic & Rat (N27) & $\mathrm{MnCl}_{2}(10-5000 \mu \mathrm{M})$ & $\begin{array}{c}\text { TROS, } \uparrow \text { mitochondria damage, } \uparrow \text { apoptosis, } \uparrow \mathrm{PKC} \delta \\
\text { activation }\end{array}$ & Mn toxicity & {$[95,96]$} \\
\hline Catecholaminergic/Dop & $\begin{array}{l}\text { Mouse (CAD), Human } \\
\text { minergic (LUHMES) }\end{array}$ & $\mathrm{MnCl}_{2}(250 \mu \mathrm{M})$ & $\begin{array}{l}\downarrow \text { TH, } \downarrow \text { REST, } \downarrow \text { NRF2, } \downarrow \text { catalase, } \downarrow \text { HO- } 1 \\
\quad \uparrow \text { oxidative stress, } \uparrow \text { inflammation }\end{array}$ & Mn toxicity; PD & [8] \\
\hline Dopaminergic & Rat (PC12) & $\mathrm{MnCl}_{2}(100 \mu \mathrm{M})$ & $\uparrow \mathrm{TH}$ phosphorylation, $\uparrow$ cytotoxicity & Mn toxicity; PD & [141] \\
\hline Dopaminergic & C. elegans & $\mathrm{MnCl}_{2}(40 \mathrm{mM})$ & 个oxidative stress & Mn toxicity; PD & [98] \\
\hline
\end{tabular}


Table 1. Cont

\begin{tabular}{|c|c|c|c|c|c|}
\hline Experimental Model & Species & Mn (Dosage/Concentration) & Cytotoxicity Mechanisms & Disease Model & References \\
\hline Cholinergic & Mouse (SN56) & $\mathrm{MnCl}_{2}(1-200 \mu \mathrm{M})$ & $\uparrow A \beta$ peptides misfolding and aggregation & $\mathrm{AD}$ & [179] \\
\hline Neuron & Mouse, Rat & $\mathrm{MnCl}_{2}(100,500,1000 \mu \mathrm{M})$ & $\uparrow F 2$-isoprostanes, $\uparrow$ lipid peroxidation & Mn toxicity & [106] \\
\hline Neuron & Rat (PC12) & $\mathrm{MnCl}_{2}(100-500 \mu \mathrm{M})$ & $\begin{array}{c}\uparrow \text { Tau phosphorylation, } \uparrow \text { impaired tau } \\
\text { degradation/aggregation, } \uparrow \text { ERK/GSK-3 } \beta \text { activation, } \\
\uparrow \text { cytotoxicity }\end{array}$ & $\mathrm{AD}$ & [180] \\
\hline Dopaminergic & Rat (MES 23.5) & $\mathrm{MnCl}_{2}(200-600 \mu \mathrm{M})$ & $\begin{array}{c}\uparrow \alpha \text { Syn levels, } \uparrow p 38 \text { activation, } \uparrow N F-\kappa B \text { activation, } \\
\uparrow N O, \uparrow a p o p t o s i s\end{array}$ & Mn toxicity; PD & [167] \\
\hline $\begin{array}{l}\text { Organotypic Brain } \\
\text { Slices }\end{array}$ & Rat & $\mathrm{MnCl}_{2}(400 \mu \mathrm{M})$ & $\begin{array}{c}\uparrow R O S, \uparrow \text { apoptosis, } \uparrow \text { LDH release, } \downarrow \text { SOD activity, } \\
\uparrow \alpha \text { Syn levels }\end{array}$ & Mn toxicity; PD & [166] \\
\hline Dopaminergic & Human (SH-SY5Y) & $\mathrm{MnCl}_{2}(500 \mu \mathrm{M})$ & $\uparrow$ Apoptosis, $\uparrow$ caspase $3, \uparrow \alpha$ Syn levels & Mn toxicity; PD & [169] \\
\hline Dopaminergic & Mouse (MN9D) & $\mathrm{MnCl}_{2}(300 \mu \mathrm{M})$ & $\uparrow$ Exosome release, $\uparrow$ cytotoxicity, $\uparrow$ Rab27a & Mn toxicity & [172] \\
\hline Dopaminergic & $\begin{array}{l}\text { Human (LUHMES), } \\
\text { Mouse (MN9D) }\end{array}$ & $\mathrm{MnCl}_{2}(10 \mathrm{mM})$ & $\uparrow \alpha$ Syn misfolding, $\uparrow \alpha$ Syn release, $\uparrow$ inflammation & Mn toxicity & {$[173]$} \\
\hline \multicolumn{6}{|l|}{ Brain regions } \\
\hline Striatum, brain stem & Rat & $\mathrm{MnCl}_{2}(25 \mathrm{mg} / \mathrm{kg})$ & $\begin{array}{c}\downarrow \text { Glutathione synthesis, } \downarrow \text { energy } \\
\uparrow \text { hypoxanthine, } \uparrow \text { xanthine, } \uparrow \text { uric acid }\end{array}$ & & [102] \\
\hline Basal ganglia & Human & NA & $\uparrow$ Astrogliosis & Mn toxicity; PD & [117] \\
\hline $\begin{array}{l}\text { Basal ganglia } \\
\text { (Striatum); } \\
\text { Substantia nigra }\end{array}$ & Rat (neonate, adult) & $\mathrm{MnCl}_{2}(10 \mathrm{mg} / \mathrm{kg})$ & $\downarrow D A$ levels & Mn toxicity; PD & {$[132,133]$} \\
\hline Striatum & Rat & $\operatorname{Mn}(100 \mathrm{mg} / \mathrm{kg})$ & $\begin{array}{c}\downarrow D A \text { levels and stores, } \downarrow \text { DA turnover, } \downarrow \text { DA release, } \\
\uparrow \text { behavioral deficits }\end{array}$ & Mn toxicity; PD & [134-136] \\
\hline $\begin{array}{l}\text { Globus pallidus } \\
\text { (Striatum), Midbrain }\end{array}$ & Human & NA & $\uparrow$ Mn levels, $\downarrow$ DA transporter & Mn toxicity & [111] \\
\hline Striatum & Rat & $\begin{array}{l}\mathrm{MnCl}_{2}(5-20 \mathrm{mg} / \mathrm{kg} \text {, daily, } \\
20 \mathrm{~d})\end{array}$ & $\uparrow$ Motor deficits, $\uparrow$ oxidative stress & Mn toxicity; PD & [21] \\
\hline Striatum & Rat & $\mathrm{MnCl}_{2}(0.5-2 \mu \mathrm{mol} / \mu \mathrm{L})$ & $\begin{array}{c}\uparrow \text { Excitotoxic lesions; } \uparrow \text { oxidative stress, } \\
\uparrow \text { mitochondrial impairment }\end{array}$ & Mn toxicity & [146] \\
\hline Striatum & Rat & $\mathrm{MnCl}_{2}(1 \mathrm{mg} / \mathrm{mL})$ & $\downarrow$ ChAT, $\downarrow$ ACh levels, & Mn toxicity & [155] \\
\hline Striatum & Mouse & $\begin{array}{l}\mathrm{MnCl}_{2}(50,100 \\
\text { and } 200 \mu \mathrm{mol} / \mathrm{kg})\end{array}$ & $\uparrow$ Autophagy dysregulation, $\uparrow$ cell injury. $\uparrow \alpha$ Syn & Mn toxicity; PD & [168] \\
\hline
\end{tabular}


Table 1. Cont.

\begin{tabular}{|c|c|c|c|c|c|}
\hline Experimental Model & Species & Mn (Dosage/Concentration) & Cytotoxicity Mechanisms & Disease Model & References \\
\hline Hippocampus & Mouse & $\begin{array}{l}\mathrm{MnCl}_{2}(100 \mu \mathrm{mol} / \mathrm{kg}, \\
5 \times / \text { week, } 6 \text { weeks })\end{array}$ & $\begin{array}{c}\uparrow \text { Impaired NMDA phosphorylation, } \uparrow \text { memory } \\
\text { dysfunction, } \uparrow \alpha \text { Syn dysregulation }\end{array}$ & Mn toxicity; $\mathrm{AD}$ & [148] \\
\hline Whole brain & Rat & $\mathrm{MnCl}_{2}(30 \mathrm{mg} / \mathrm{kg})$ & $\begin{array}{l}\downarrow \mathrm{AChE}, \uparrow \text { oxidative and nitrosative stress, } \\
\uparrow \text { intracellular } \mathrm{Ca}^{2+} \text { accumulation }\end{array}$ & Mn toxicity & [154] \\
\hline Whole brain & Rat & $\mathrm{MnCl}_{2}(3 \mathrm{mg} / \mathrm{mL})$ & $\downarrow$ GABA, $\uparrow$ seizure duration, $\downarrow$ seizure threshold & Mn toxicity & [25] \\
\hline Forebrain & Rat & $\mathrm{MnCl}_{2}(10 \mathrm{mM})$ & $\downarrow$ GABA uptake & Mn toxicity & [159] \\
\hline Thalamus & Rat & $\mathrm{MnCl}_{2}(1 \mathrm{~g} / \mathrm{L})$ & $\uparrow \mathrm{GABA}$ & Mn toxicity & [160] \\
\hline Substantia nigra & Mouse & $\begin{array}{l}\mathrm{MnCl}_{2}(30 \mathrm{mg} / \mathrm{kg} \\
\text { daily } / 3 \mathrm{wks})\end{array}$ & $\begin{array}{c}\downarrow \text { TH, } \downarrow \text { EAAT1/GLAST, } \downarrow \text { EAAT2/GLT-1, } \uparrow Y Y 1, \\
\uparrow \text { HDAC-YY1 interaction, } \uparrow \text { motor deficits, } \\
\uparrow \text { microglial activation }\end{array}$ & Mn toxicity; PD & [8] \\
\hline Midbrain, cerebellum & Mouse & $\mathrm{MnCl}_{2}(10 \mathrm{mg} / \mathrm{mL})$ & $\downarrow C h A T, \uparrow$ impaired choline uptake & $\begin{array}{l}\text { Mn toxicity; } \\
\text { encephalopathy }\end{array}$ & [156] \\
\hline $\begin{array}{l}\text { Hippocampus, cortex, } \\
\text { and basal ganglia }\end{array}$ & Rat & $\mathrm{MnCl}_{2}$ & $\begin{array}{c}\downarrow \text { Choline transporter, } \downarrow \text { choline uptake, } \\
\quad \downarrow \text { homovanillic acid }\end{array}$ & Mn toxicity & [157] \\
\hline Prefrontal cortex & Mouse & $\mathrm{MnCl}_{2}(5 \mathrm{mg} / \mathrm{kg}$, daily/22 d) & $\begin{array}{l}\downarrow \text { ACh activity, } \downarrow \text { nicotinic ACh receptors, } \uparrow \text { impaired } \\
\text { spatial memory }\end{array}$ & Mn toxicity; $\mathrm{AD}$ & [158] \\
\hline Frontal Cortex & Nonhuman primate & $\begin{array}{c}\mathrm{Mn}(3.3-5.0,5.0-6.7 \\
8.3-10 \mathrm{mg} \mathrm{Mn} / \mathrm{kg})\end{array}$ & $\uparrow \alpha$ Syn aggregation, $\uparrow$ apoptosis & Mn toxicity; PD & [165] \\
\hline Frontal cortex & Nonhuman primate & NA & $\begin{array}{c}\uparrow A \beta \text { precursor protein } 1, \uparrow A \beta \text { expression, } \\
\uparrow \text { cytotoxicity }\end{array}$ & $\mathrm{AD}$ & {$[176,177]$} \\
\hline Parietal cortex & Human & NA & $\begin{array}{c}\uparrow \text { Mn levels, } \uparrow A D \text { pathology, } \uparrow \text { impaired } A \beta \text { and } \\
\text { ApoE function }\end{array}$ & $\mathrm{AD}$ & [174] \\
\hline $\begin{array}{l}\text { Cerebral cortex, } \\
\text { hippocampus }\end{array}$ & Mouse & $\mathrm{MnCl}_{2}(0.36 \mathrm{mg} / \mathrm{mL}, 5 \mathrm{mos})$. & $\begin{array}{c}\uparrow \mathrm{A} \beta \text { expression, } \uparrow \beta \text { - and } \gamma \text {-secretase cleavage } \\
\text { activities }\end{array}$ & $\mathrm{AD}$ & {$[178]$} \\
\hline Blood & Human & NA & $\begin{array}{c}\uparrow M n \text { levels, } \underset{\uparrow}{\uparrow \text { impaired } A \beta \text { degradation/aggregation, }} \\
\uparrow \text { cognitive impairment }\end{array}$ & $\mathrm{AD}$ & [175] \\
\hline
\end{tabular}

$\uparrow$ : increased. $\downarrow$ : decreased. NA, not applicable/not available. CAD: Cath.a differentiated. LRRK2: leucine rich repeat kinase 2. LUHMES: Lund human mesencephalic. TNF- $\alpha$ : tumor necrosis factor alpha. NF-kB: nuclear factor kappa-light-chain enhancer of B cells. IL-1 $\beta$ : interleukin $1 \beta$. IL-6: interleukin 6 . iNOS: inducible nitric oxide synthase. NO: nitric oxide SOD: superoxide dismutase. GPx: glutathione peroxidase. LDH: lactate dehydrogenase. ROS: reactive oxygen species. EAAT1/2: excitatory amino acid transporter 1/2. GLAST: glutamate aspartate transporter 1. GLT: glutamate transporter 1 PKC: protein kinase C. GSH: glutathione. NRF2: Nuclear factor erythroid 2-related factor 2. HO-1: Heme oxygenase-1. REST: repressor element-1 silencing transcription factor. TH: tyrosine hydroxylase. DA: dopamine. $\alpha$ Syn: $\alpha$-synuclein. A $\beta$ : amyloid- $\beta$. ApoE: apolipoprotein E. ChAT: choline acetyltransferase. ACh: acetylcholine. GABA: gamma aminobutyric acid. ERK: extracellular signal-regulated kinase: GSK-3ß: HDAC: histone deacetylase. YY1: Yin Yang 1. NMDA: N-methyl D-aspartate. PD: Parkinson's disease. AD: Alzheimer's disease. 


\subsection{Aß Aggregation}

Chronic exposure to high levels of Mn also serves as a risk factor in $\mathrm{AD}$, as elevated levels of Mn were found in the parietal cortex and other regions of AD patients' brains and A $\beta$ aggregates in those regions and cognitive impairment $[174,175]$. Mn also induced the hyperphosphorylation of tau, another hallmark of AD, in PC12 neuronal cells [175]. Several mechanisms of Mn-induced toxicity contribute to the formation of $A \beta$ plaques or amyloidogenesis in in vitro and in vivo $A D$ models. Studies have shown that Mn increased the expression of A $\beta$ precursor-like protein 1 (APLP1) and the formation of $A \beta$ plaques in the frontal cortex of nonhuman primates [176,177]. Mn induced $A \beta$ plaque formation and increased $A \beta$ mRNA levels, as well as $A \beta$ protein levels, by increasing $\beta$-secretase (BACE) and $\gamma$-secretase cleavage activities in the cerebral cortex and hippocampus of an $\mathrm{AD}$ mouse model, particularly in the microglia [178], suggesting that Mn-induced microglial inflammation likely contributes to amyloidogenesis and AD pathology. Mn could also increase the aggregation of misfolded $A \beta$ peptides in cholinergic neurons via the dysregulation of proteasome $20 \mathrm{~S}$ and heat shock proteins [179]. These findings indicate that $\mathrm{Mn}$ may contribute to $\mathrm{AD}$ pathogenesis via the $\mathrm{Mn}$-induced dysregulation of $\mathrm{A} \beta$ production.

\section{Concluding Remarks}

$\mathrm{Mn}$ is an essential trace element required by various physiological processes in the body; however, chronic exposure to elevated Mn levels induces neurological disorders. Metal transporters are important in regulating $\mathrm{Mn}$ transport to maintain physiological levels of $\mathrm{Mn}$ in the body. The role of several Mn transporters was discussed to provide a better understanding of how Mn accumulates in the brain regions where it causes the most neuronal injury. Additionally, several aspects of the mechanisms of Mn-induced neurotoxicity, such as oxidative stress, inflammation, the dysregulation of neurotransmission, and $\alpha$ Syn aggregation, were reviewed. However, further investigations are needed to delineate the complex nature of the mechanisms of Mn-induced neurotoxicity, which could lead to identifying molecular targets in treating Mn toxicity, as well as other neurodegenerative diseases sharing common pathological features.

Author Contributions: Conceptualization, I.N.-D. and E.P.; writing-original draft preparation, I.N.-D., E.P., and A.D.; writing-review and editing, E.L., E.P., M.A., and K.F.A.S.; supervision, E.L.; and funding acquisition, E.L., M.A., and K.F.A.S. All authors have read and agreed to the published version of the manuscript.

Funding: This research was funded by the National Institute of Environmental Health Sciences: R01 ES024756 (EL), R01 ES031282 (EL), U54 MD007582 (KS), R01 ES10563 (MA), and R01 ES07331 (MA).

Conflicts of Interest: The authors declare no conflict of interest.

\section{References}

1. Chen, P.; Bornhorst, J.; Aschner, M. Manganese metabolism in humans. Front. Biosci. 2018, 23, $1655-1679$. [CrossRef]

2. Aschner, J.L.; Aschner, M. Nutritional aspects of manganese homeostasis. Mol. Asp. Med. 2005, 26, 353-362. [CrossRef]

3. Reddi, A.R.; Jensen, L.T.; Naranuntarat, A.; Rosenfeld, L.; Leung, E.; Shah, R.; Culotta, V.C. The overlapping roles of manganese and $\mathrm{Cu} / \mathrm{Zn}$ SOD in oxidative stress protection. Free Radic. Biol. Med. 2009, 46, 154-162. [CrossRef]

4. Vadaie, N.; Hulinsky, R.S.; Jarvis, D.L. Identification and characterization of a Drosophila melanogaster ortholog of human beta1,4-galactosyltransferase VII. Glycobiology 2002, 12, 589-597. [CrossRef]

5. Lees, A.J.; Hardy, J.; Revesz, T. Parkinson's disease. Lancet 2009, 373, 2055-2066. [CrossRef]

6. Long, Z.; Jiang, Y.M.; Li, X.R.; Fadel, W.; Xu, J.; Yeh, C.L.; Long, L.L.; Luo, H.L.; Harezlak, J.; Murdoch, J.B.; et al. Vulnerability of welders to manganese exposure-a neuroimaging study. Neurotoxicology 2014, 45, 285-292. [CrossRef]

7. Park, R.M. Neurobehavioral deficits and parkinsonism in occupations with manganese exposure: A review of methodological issues in the epidemiological literature. Saf. Health Work 2013, 4, 123-135. [CrossRef] 
8. Pajarillo, E.; Johnson, J., Jr.; Rizor, A.; Nyarko-Danquah, I.; Adinew, G.; Bornhorst, J.; Stiboller, M.; Schwerdtle, T.; Son, D.S.; Aschner, M.; et al. Astrocyte-specific deletion of the transcription factor Yin Yang 1 in murine substantia nigra mitigates manganese-induced dopaminergic neurotoxicity. J. Biol. Chem. 2020. [CrossRef]

9. Bowman, A.B.; Kwakye, G.F.; Herrero Hernandez, E.; Aschner, M. Role of manganese in neurodegenerative diseases. J. Trace Elem. Med. Biol. 2011, 25, 191-203. [CrossRef]

10. Leblondel, G.; Allain, P. Manganese transport by caco-2 cells. Biol. Trace Elem. Res. 1999, 67, 13-28. [CrossRef]

11. Wolff, N.A.; Garrick, M.D.; Zhao, L.; Garrick, L.M.; Ghio, A.J.; Thevenod, F. A role for divalent metal transporter (DMT1) in mitochondrial uptake of iron and manganese. Sci. Rep. 2018, 8, 211. [CrossRef]

12. Malecki, E.A.; Devenyi, A.G.; Beard, J.L.; Connor, J.R. Existing and emerging mechanisms for transport of iron and manganese to the brain. J. Neurosci. Res. 1999, 56, 113-122. [CrossRef]

13. Park, J.H.; Hogrebe, M.; Gruneberg, M.; DuChesne, I.; von der Heiden, A.L.; Reunert, J.; Schlingmann, K.P.; Boycott, K.M.; Beaulieu, C.L.; Mhanni, A.A.; et al. SLC39A8 Deficiency: A Disorder of Manganese Transport and Glycosylation. Am. J. Hum. Genet. 2015, 97, 894-903. [CrossRef]

14. Liuzzi, J.P.; Aydemir, F.; Nam, H.; Knutson, M.D.; Cousins, R.J. Zip14 (Slc39a14) mediates non-transferrinbound iron uptake into cells. Proc. Natl. Acad. Sci. USA 2006, 103, 13612-13617. [CrossRef]

15. Kim, Y.V.; Di Cello, F.; Hillaire, C.S.; Kim, K.S. Differential Ca2+ signaling by thrombin and protease-activated receptor-1-activating peptide in human brain microvascular endothelial cells. Am. J. Physiol. Cell Physiol. 2004, 286, C31-C42. [CrossRef]

16. Crossgrove, J.S.; Allen, D.D.; Bukaveckas, B.L.; Rhineheimer, S.S.; Yokel, R.A. Manganese distribution across the blood-brain barrier. I. Evidence for carrier-mediated influx of managanese citrate as well as manganese and manganese transferrin. Neurotoxicology 2003, 24, 3-13. [CrossRef]

17. Choi, E.K.; Nguyen, T.T.; Iwase, S.; Seo, Y.A. Ferroportin disease mutations influence manganese accumulation and cytotoxicity. FASEB J. Off. Publ. Fed. Am. Soc. Exp. Biol. 2019, 33, 2228-2240. [CrossRef]

18. Ng, E.; Lind, P.M.; Lindgren, C.; Ingelsson, E.; Mahajan, A.; Morris, A.; Lind, L. Genome-wide association study of toxic metals and trace elements reveals novel associations. Hum. Mol. Genet. 2015, 24, 4739-4745. [CrossRef]

19. Chen, P.; Chakraborty, S.; Mukhopadhyay, S.; Lee, E.; Paoliello, M.M.; Bowman, A.B.; Aschner, M. Manganese homeostasis in the nervous system. J. Neurochem. 2015, 134, 601-610. [CrossRef]

20. Chen, C.J.; Ou, Y.C.; Lin, S.Y.; Liao, S.L.; Chen, S.Y.; Chen, J.H. Manganese modulates pro-inflammatory gene expression in activated glia. Neurochem. Int. 2006, 49, 62-71. [CrossRef]

21. Cordova, F.M.; Aguiar, A.S., Jr.; Peres, T.V.; Lopes, M.W.; Goncalves, F.M.; Pedro, D.Z.; Lopes, S.C.; Pilati, C.; Prediger, R.D.; Farina, M.; et al. Manganese-exposed developing rats display motor deficits and striatal oxidative stress that are reversed by Trolox. Arch. Toxicol. 2013, 87, 1231-1244. [CrossRef]

22. Milatovic, D.; Gupta, R.C.; Yu, Y.; Zaja-Milatovic, S.; Aschner, M. Protective effects of antioxidants and anti-inflammatory agents against manganese-induced oxidative damage and neuronal injury. Toxicol. Appl. Pharm. 2011, 256, 219-226. [CrossRef]

23. Stephenson, A.P.; Schneider, J.A.; Nelson, B.C.; Atha, D.H.; Jain, A.; Soliman, K.F.; Aschner, M.; Mazzio, E.; Renee Reams, R. Manganese-induced oxidative DNA damage in neuronal SH-SY5Y cells: Attenuation of thymine base lesions by glutathione and N-acetylcysteine. Toxicol. Lett. 2013, 218, 299-307. [CrossRef]

24. Calabresi, P.; Ammassari-Teule, M.; Gubellini, P.; Sancesario, G.; Morello, M.; Centonze, D.; Marfia, G.A.; Saulle, E.; Passino, E.; Picconi, B.; et al. A synaptic mechanism underlying the behavioral abnormalities induced by manganese intoxication. Neurobiol. Dis. 2001, 8, 419-432. [CrossRef]

25. Ali, M.M.; Murthy, R.C.; Saxena, D.K.; Chandra, S.V. Effect of low protein diet on manganese neurotoxicity: II. Brain GABA and seizure susceptibility. Neurobehav. Toxicol. Teratol. 1983, 5, 385-389.

26. Spadoni, F.; Stefani, A.; Morello, M.; Lavaroni, F.; Giacomini, P.; Sancesario, G. Selective vulnerability of pallidal neurons in the early phases of manganese intoxication. Exp. Brain Res. 2000, 135, 544-551. [CrossRef]

27. Huang, C.C.; Weng, Y.H.; Lu, C.S.; Chu, N.S.; Yen, T.C. Dopamine transporter binding in chronic manganese intoxication. J. Neurol. 2003, 250, 1335-1339. [CrossRef]

28. Cai, T.; Yao, T.; Zheng, G.; Chen, Y.; Du, K.; Cao, Y.; Shen, X.; Chen, J.; Luo, W. Manganese induces the overexpression of alpha-synuclein in PC12 cells via ERK activation. Brain Res. 2010, 1359, 201-207. [CrossRef] 
29. Nischwitz, V.; Berthele, A.; Michalke, B. Speciation analysis of selected metals and determination of their total contents in paired serum and cerebrospinal fluid samples: An approach to investigate the permeability of the human blood-cerebrospinal fluid-barrier. Anal. Chim. Acta 2008, 627, 258-269. [CrossRef]

30. Peres, T.V.; Schettinger, M.R.; Chen, P.; Carvalho, F.; Avila, D.S.; Bowman, A.B.; Aschner, M. Manganese-induced neurotoxicity: A review of its behavioral consequences and neuroprotective strategies. BMC Pharm. Toxicol. 2016, 17, 57. [CrossRef]

31. Gunshin, H.; Mackenzie, B.; Berger, U.V.; Gunshin, Y.; Romero, M.F.; Boron, W.F.; Nussberger, S.; Gollan, J.L.; Hediger, M.A. Cloning and characterization of a mammalian proton-coupled metal-ion transporter. Nature 1997, 388, 482-488. [CrossRef]

32. Garrick, M.D.; Dolan, K.G.; Horbinski, C.; Ghio, A.J.; Higgins, D.; Porubcin, M.; Moore, E.G.; Hainsworth, L.N.; Umbreit, J.N.; Conrad, M.E.; et al. DMT1: A mammalian transporter for multiple metals. Biometals 2003, 16, 41-54. [CrossRef]

33. Gruenheid, S.; Cellier, M.; Vidal, S.; Gros, P. Identification and characterization of a second mouse Nramp gene. Genomics 1995, 25, 514-525. [CrossRef]

34. Vidal, S.; Belouchi, A.M.; Cellier, M.; Beatty, B.; Gros, P. Cloning and characterization of a second human NRAMP gene on chromosome 12q13. Mamm. Genome 1995, 6, 224-230. [CrossRef]

35. Gruenheid, S.; Canonne-Hergaux, F.; Gauthier, S.; Hackam, D.J.; Grinstein, S.; Gros, P. The iron transport protein NRAMP2 is an integral membrane glycoprotein that colocalizes with transferrin in recycling endosomes. J. Exp. Med. 1999, 189, 831-841. [CrossRef]

36. Wolff, N.A.; Ghio, A.J.; Garrick, L.M.; Garrick, M.D.; Zhao, L.; Fenton, R.A.; Thevenod, F. Evidence for mitochondrial localization of divalent metal transporter 1 (DMT1). FASEB J. Off. Publ. Fed. Am. Soc. Exp. Biol. 2014, 28, 2134-2145. [CrossRef]

37. Wolff, N.A.; Garrick, L.M.; Zhao, L.; Garrick, M.D.; Thevenod, F. Mitochondria represent another locale for the divalent metal transporter 1 (DMT1). Channels 2014, 8, 458-466. [CrossRef]

38. Priwitzerova, M.; Pospisilova, D.; Prchal, J.T.; Indrak, K.; Hlobilkova, A.; Mihal, V.; Ponka, P.; Divoky, V. Severe hypochromic microcytic anemia caused by a congenital defect of the iron transport pathway in erythroid cells. Blood 2004, 103, 3991-3992. [CrossRef]

39. Mims, M.P.; Guan, Y.; Pospisilova, D.; Priwitzerova, M.; Indrak, K.; Ponka, P.; Divoky, V.; Prchal, J.T. Identification of a human mutation of DMT1 in a patient with microcytic anemia and iron overload. Blood 2005, 105, 1337-1342. [CrossRef]

40. Andrews, N.C. The iron transporter DMT1. Int. J. Biochem. Cell Biol. 1999, 31, 991-994. [CrossRef]

41. Lee, P.L.; Gelbart, T.; West, C.; Halloran, C.; Beutler, E. The human Nramp2 gene: Characterization of the gene structure, alternative splicing, promoter region and polymorphisms. Blood Cells Mol. Dis. 1998, 24, 199-215. [CrossRef]

42. Huang, E.; Ong, W.Y.; Connor, J.R. Distribution of divalent metal transporter-1 in the monkey basal ganglia. Neuroscience 2004, 128, 487-496. [CrossRef]

43. Wang, X.S.; Ong, W.Y.; Connor, J.R. A light and electron microscopic study of the iron transporter protein DMT-1 in the monkey cerebral neocortex and hippocampus. J. Neurocytol. 2001, 30, 353-360. [CrossRef]

44. Fu, S.; O'Neal, S.; Hong, L.; Jiang, W.; Zheng, W. Elevated adult neurogenesis in brain subventricular zone following in vivo manganese exposure: Roles of copper and DMT1. Toxicol. Sci. 2015, 143, 482-498. [CrossRef]

45. Thompson, K.; Molina, R.M.; Donaghey, T.; Schwob, J.E.; Brain, J.D.; Wessling-Resnick, M. Olfactory uptake of manganese requires DMT1 and is enhanced by anemia. FASEB J. Off. Publ. Fed. Am. Soc. Exp. Biol. 2007, 21, 223-230. [CrossRef]

46. Crossgrove, J.S.; Yokel, R.A. Manganese distribution across the blood-brain barrier III. The divalent metal transporter-1 is not the major mechanism mediating brain manganese uptake. Neurotoxicology 2004, 25, 451-460. [CrossRef]

47. Salazar, J.; Mena, N.; Hunot, S.; Prigent, A.; Alvarez-Fischer, D.; Arredondo, M.; Duyckaerts, C.; Sazdovitch, V.; Zhao, L.; Garrick, L.M.; et al. Divalent metal transporter 1 (DMT1) contributes to neurodegeneration in animal models of Parkinson's disease. Proc. Natl. Acad. Sci. USA 2008, 105, 18578-18583. [CrossRef]

48. He, Q.; Du, T.; Yu, X.; Xie, A.; Song, N.; Kang, Q.; Yu, J.; Tan, L.; Xie, J.; Jiang, H. DMT1 polymorphism and risk of Parkinson's disease. Neurosci. Lett. 2011, 501, 128-131. [CrossRef] 
49. Fujishiro, H.; Doi, M.; Enomoto, S.; Himeno, S. High sensitivity of RBL-2H3 cells to cadmium and manganese: An implication of the role of ZIP8. Metallomics 2011, 3, 710-718. [CrossRef]

50. Wang, C.Y.; Jenkitkasemwong, S.; Duarte, S.; Sparkman, B.K.; Shawki, A.; Mackenzie, B.; Knutson, M.D. ZIP8 is an iron and zinc transporter whose cell-surface expression is up-regulated by cellular iron loading. J. Biol. Chem. 2012, 287, 34032-34043. [CrossRef]

51. Uhlen, M.; Fagerberg, L.; Hallstrom, B.M.; Lindskog, C.; Oksvold, P.; Mardinoglu, A.; Sivertsson, A.; Kampf, C.; Sjostedt, E.; Asplund, A.; et al. Proteomics. Tissue-based map of the human proteome. Science 2015, 347, 1260419. [CrossRef]

52. Scheiber, I.F.; Alarcon, N.O.; Zhao, N. Manganese Uptake by A549 Cells is Mediated by Both ZIP8 and ZIP14. Nutrients 2019, 11. [CrossRef]

53. Steimle, B.L.; Smith, F.M.; Kosman, D.J. The solute carriers ZIP8 and ZIP14 regulate manganese accumulation in brain microvascular endothelial cells and control brain manganese levels. J. Biol. Chem. 2019, 294, 19197-19208. [CrossRef]

54. Morgan, S.E.; Schroten, H.; Ishikawa, H.; Zhao, N. Localization of ZIP14 and ZIP8 in HIBCPP Cells. Brain Sci. 2020, 10. [CrossRef]

55. Taylor, K.M.; Morgan, H.E.; Johnson, A.; Nicholson, R.I. Structure-function analysis of a novel member of the LIV-1 subfamily of zinc transporters, ZIP14. FEBS Lett. 2005, 579, 427-432. [CrossRef]

56. Girijashanker, K.; He, L.; Soleimani, M.; Reed, J.M.; Li, H.; Liu, Z.; Wang, B.; Dalton, T.P.; Nebert, D.W. Slc39a14 gene encodes ZIP14, a metal/bicarbonate symporter: Similarities to the ZIP8 transporter. Mol. Pharm. 2008, 73, 1413-1423. [CrossRef]

57. Guthrie, G.J.; Aydemir, T.B.; Troche, C.; Martin, A.B.; Chang, S.M.; Cousins, R.J. Influence of ZIP14 (slc39A14) on intestinal zinc processing and barrier function. Am. J. Physiol. Gastrointest Liver Physiol. 2015, 308, G171-G178. [CrossRef]

58. Tuschl, K.; Meyer, E.; Valdivia, L.E.; Zhao, N.; Dadswell, C.; Abdul-Sada, A.; Hung, C.Y.; Simpson, M.A.; Chong, W.K.; Jacques, T.S.; et al. Mutations in SLC39A14 disrupt manganese homeostasis and cause childhood-onset parkinsonism-dystonia. Nat. Commun. 2016, 7, 11601. [CrossRef]

59. Jenkitkasemwong, S.; Akinyode, A.; Paulus, E.; Weiskirchen, R.; Hojyo, S.; Fukada, T.; Giraldo, G.; Schrier, J.; Garcia, A.; Janus, C.; et al. SLC39A14 deficiency alters manganese homeostasis and excretion resulting in brain manganese accumulation and motor deficits in mice. Proc. Natl. Acad. Sci. USA 2018, 115, E1769-E1778. [CrossRef]

60. Marti-Sanchez, L.; Ortigoza-Escobar, J.D.; Darling, A.; Villaronga, M.; Baide, H.; Molero-Luis, M.; Batllori, M.; Vanegas, M.I.; Muchart, J.; Aquino, L.; et al. Hypermanganesemia due to mutations in SLC39A14: Further insights into Mn deposition in the central nervous system. Orphanet. J. Rare Dis. 2018, 13, 28. [CrossRef]

61. Aschner, M.; Gannon, M. Manganese (Mn) transport across the rat blood-brain barrier: Saturable and transferrin-dependent transport mechanisms. Brain Res. Bull 1994, 33, 345-349. [CrossRef]

62. Gunter, T.E.; Gerstner, B.; Gunter, K.K.; Malecki, J.; Gelein, R.; Valentine, W.M.; Aschner, M.; Yule, D.I. Manganese transport via the transferrin mechanism. Neurotoxicology 2013, 34, 118-127. [CrossRef]

63. Moos, T.; Morgan, E.H. Transferrin and transferrin receptor function in brain barrier systems. Cell Mol. Neurobiol. 2000, 20, 77-95. [CrossRef]

64. Kumar, K.K.; Lowe, E.W., Jr.; Aboud, A.A.; Neely, M.D.; Redha, R.; Bauer, J.A.; Odak, M.; Weaver, C.D.; Meiler, J.; Aschner, M.; et al. Cellular manganese content is developmentally regulated in human dopaminergic neurons. Sci. Rep. 2014, 4, 6801. [CrossRef]

65. Michalke, B.; Berthele, A.; Mistriotis, P.; Ochsenkuhn-Petropoulou, M.; Halbach, S. Manganese species from human serum, cerebrospinal fluid analyzed by size exclusion chromatography-, capillary electrophoresis coupled to inductively coupled plasma mass spectrometry. J. Trace Elem. Med. Biol. 2007, 21 (Suppl. 1), 4-9. [CrossRef]

66. Yokel, R.A. Manganese flux across the blood-brain barrier. Neuromol. Med. 2009, 11, 297-310. [CrossRef]

67. Ducic, T.; Barski, E.; Salome, M.; Koch, J.C.; Bahr, M.; Lingor, P. X-ray fluorescence analysis of iron and manganese distribution in primary dopaminergic neurons. J. Neurochem. 2013, 124, 250-261. [CrossRef]

68. Abboud, S.; Haile, D.J. A novel mammalian iron-regulated protein involved in intracellular iron metabolism. J. Biol. Chem. 2000, 275, 19906-19912. [CrossRef]

69. Donovan, A.; Lima, C.A.; Pinkus, J.L.; Pinkus, G.S.; Zon, L.I.; Robine, S.; Andrews, N.C. The iron exporter ferroportin/Slc40a1 is essential for iron homeostasis. Cell Metab. 2005, 1, 191-200. [CrossRef] 
70. Wu, L.J.; Leenders, A.G.; Cooperman, S.; Meyron-Holtz, E.; Smith, S.; Land, W.; Tsai, R.Y.; Berger, U.V.; Sheng, Z.H.; Rouault, T.A. Expression of the iron transporter ferroportin in synaptic vesicles and the blood-brain barrier. Brain Res. 2004, 1001, 108-117. [CrossRef]

71. Yin, Z.; Jiang, H.; Lee, E.S.; Ni, M.; Erikson, K.M.; Milatovic, D.; Bowman, A.B.; Aschner, M. Ferroportin is a manganese-responsive protein that decreases manganese cytotoxicity and accumulation. J. Neurochem. 2010, 112, 1190-1198. [CrossRef] [PubMed]

72. Leyva-Illades, D.; Chen, P.; Zogzas, C.E.; Hutchens, S.; Mercado, J.M.; Swaim, C.D.; Morrisett, R.A.; Bowman, A.B.; Aschner, M.; Mukhopadhyay, S. SLC30A10 is a cell surface-localized manganese efflux transporter, and parkinsonism-causing mutations block its intracellular trafficking and efflux activity. J. Neurosci. 2014, 34, 14079-14095. [CrossRef] [PubMed]

73. Tuschl, K.; Clayton, P.T.; Gospe, S.M., Jr.; Gulab, S.; Ibrahim, S.; Singhi, P.; Aulakh, R.; Ribeiro, R.T.; Barsottini, O.G.; Zaki, M.S.; et al. Syndrome of hepatic cirrhosis, dystonia, polycythemia, and hypermanganesemia caused by mutations in SLC30A10, a manganese transporter in man. Am. J. Hum. Genet. 2012, 90, 457-466. [CrossRef] [PubMed]

74. Quadri, M.; Federico, A.; Zhao, T.; Breedveld, G.J.; Battisti, C.; Delnooz, C.; Severijnen, L.A.; Di Toro Mammarella, L.; Mignarri, A.; Monti, L.; et al. Mutations in SLC30A10 cause parkinsonism and dystonia with hypermanganesemia, polycythemia, and chronic liver disease. Am. J. Hum. Genet. 2012, 90, 467-477. [CrossRef] [PubMed]

75. Tuschl, K.; Mills, P.B.; Parsons, H.; Malone, M.; Fowler, D.; Bitner-Glindzicz, M.; Clayton, P.T. Hepatic cirrhosis, dystonia, polycythaemia and hypermanganesaemia-A new metabolic disorder. J. Inherit Metab Dis. 2008, 31, 151-163. [CrossRef] [PubMed]

76. Taylor, C.A.; Hutchens, S.; Liu, C.; Jursa, T.; Shawlot, W.; Aschner, M.; Smith, D.R.; Mukhopadhyay, S. SLC30A10 transporter in the digestive system regulates brain manganese under basal conditions while brain SLC30A10 protects against neurotoxicity. J. Biol. Chem. 2019, 294, 1860-1876. [CrossRef]

77. Robison, G.; Sullivan, B.; Cannon, J.R.; Pushkar, Y. Identification of dopaminergic neurons of the substantia nigra pars compacta as a target of manganese accumulation. Metallomics 2015, 7, 748-755. [CrossRef]

78. Carmona, A.; Roudeau, S.; Perrin, L.; Veronesi, G.; Ortega, R. Environmental manganese compounds accumulate as $\mathrm{Mn}(\mathrm{II})$ within the Golgi apparatus of dopamine cells: Relationship between speciation, subcellular distribution, and cytotoxicity. Metallomics 2014, 6, 822-832. [CrossRef]

79. Kalia, K.; Jiang, W.; Zheng, W. Manganese accumulates primarily in nuclei of cultured brain cells. Neurotoxicology 2008, 29, 466-470. [CrossRef]

80. Gavin, C.E.; Gunter, K.K.; Gunter, T.E. Manganese and calcium transport in mitochondria: Implications for manganese toxicity. Neurotoxicology 1999, 20, 445-453.

81. Archibald, F.S.; Tyree, C. Manganese poisoning and the attack of trivalent manganese upon catecholamines. Arch. Biochem. Biophys. 1987, 256, 638-650. [CrossRef]

82. Forman, H.J.; Boveris, A. Chapter 3-Superoxide radical and hydrogen peroxide in mitochondria. In Free Radicals in Biology; Pryor, W.A., Ed.; Elsevier Inc.: New York, NY, USA, 1982; pp. 65-90. [CrossRef]

83. Covy, J.P.; Waxman, E.A.; Giasson, B.I. Characterization of cellular protective effects of ATP13A2/PARK9 expression and alterations resulting from pathogenic mutants. J. Neurosci. Res. 2012, 90, 2306-2316. [CrossRef] [PubMed]

84. Tan, J.; Zhang, T.; Jiang, L.; Chi, J.; Hu, D.; Pan, Q.; Wang, D.; Zhang, Z. Regulation of intracellular manganese homeostasis by Kufor-Rakeb syndrome-associated ATP13A2 protein. J. Biol. Chem. 2011, 286, 29654-29662. [CrossRef] [PubMed]

85. Hinarejos, I.; Machuca-Arellano, C.; Sancho, P.; Espinos, C. Mitochondrial Dysfunction, Oxidative Stress and Neuroinflammation in Neurodegeneration with Brain Iron Accumulation (NBIA). Antioxidants 2020, 9, 1020. [CrossRef] [PubMed]

86. Gitler, A.D.; Chesi, A.; Geddie, M.L.; Strathearn, K.E.; Hamamichi, S.; Hill, K.J.; Caldwell, K.A.; Caldwell, G.A.; Cooper, A.A.; Rochet, J.C.; et al. Alpha-synuclein is part of a diverse and highly conserved interaction network that includes PARK9 and manganese toxicity. Nat. Genet. 2009, 41, 308-315. [CrossRef] [PubMed]

87. Missiaen, L.; Raeymaekers, L.; Dode, L.; Vanoevelen, J.; Van Baelen, K.; Parys, J.B.; Callewaert, G.; De Smedt, H.; Segaert, S.; Wuytack, F. SPCA1 pumps and Hailey-Hailey disease. Biochem. Biophys. Res. Commun. 2004, 322, 1204-1213. [CrossRef] 
88. Murin, R.; Verleysdonk, S.; Raeymaekers, L.; Kaplan, P.; Lehotsky, J. Distribution of secretory pathway Ca2+ ATPase (SPCA1) in neuronal and glial cell cultures. Cell Mol. Neurobiol. 2006, 26, 1355-1365. [CrossRef]

89. Nishito, Y.; Tsuji, N.; Fujishiro, H.; Takeda, T.A.; Yamazaki, T.; Teranishi, F.; Okazaki, F.; Matsunaga, A.; Tuschl, K.; Rao, R.; et al. Direct Comparison of Manganese Detoxification/Efflux Proteins and Molecular Characterization of ZnT10 Protein as a Manganese Transporter. J. Biol. Chem. 2016, 291, 14773-14787. [CrossRef]

90. Sepulveda, M.R.; Vanoevelen, J.; Raeymaekers, L.; Mata, A.M.; Wuytack, F. Silencing the SPCA1 (secretory pathway Ca2+-ATPase isoform 1) impairs $\mathrm{Ca} 2+$ homeostasis in the Golgi and disturbs neural polarity. J. Neurosci. 2009, 29, 12174-12182. [CrossRef]

91. Zhang, S.; Zhou, Z.; Fu, J. Effect of manganese chloride exposure on liver and brain mitochondria function in rats. Env. Res. 2003, 93, 149-157. [CrossRef]

92. Centonze, D.; Gubellini, P.; Bernardi, G.; Calabresi, P. Impaired excitatory transmission in the striatum of rats chronically intoxicated with manganese. Exp. Neurol. 2001, 172, 469-476. [CrossRef] [PubMed]

93. Filipov, N.M.; Dodd, C.A. Role of glial cells in manganese neurotoxicity. J. Appl. Toxicol. 2012, 32, 310-317. [CrossRef] [PubMed]

94. Harischandra, D.S.; Jin, H.; Anantharam, V.; Kanthasamy, A.; Kanthasamy, A.G. alpha-Synuclein protects against manganese neurotoxic insult during the early stages of exposure in a dopaminergic cell model of Parkinson's disease. Toxicol. Sci. 2015, 143, 454-468. [CrossRef] [PubMed]

95. Latchoumycandane, C.; Anantharam, V.; Kitazawa, M.; Yang, Y.; Kanthasamy, A.; Kanthasamy, A.G. Protein kinase Cdelta is a key downstream mediator of manganese-induced apoptosis in dopaminergic neuronal cells. J. Pharm. Exp. 2005, 313, 46-55. [CrossRef] [PubMed]

96. Anantharam, V.; Kitazawa, M.; Wagner, J.; Kaul, S.; Kanthasamy, A.G. Caspase-3-dependent proteolytic cleavage of protein kinase Cdelta is essential for oxidative stress-mediated dopaminergic cell death after exposure to methylcyclopentadienyl manganese tricarbonyl. J. Neurosci. 2002, 22, 1738-1751. [CrossRef] [PubMed]

97. Roth, J.A.; Li, Z.; Sridhar, S.; Khoshbouei, H. The effect of manganese on dopamine toxicity and dopamine transporter (DAT) in control and DAT transfected HEK cells. Neurotoxicology 2013, 35, 121-128. [CrossRef]

98. Benedetto, A.; Au, C.; Avila, D.S.; Milatovic, D.; Aschner, M. Extracellular dopamine potentiates mn-induced oxidative stress, lifespan reduction, and dopaminergic neurodegeneration in a BLI-3-dependent manner in Caenorhabditis elegans. PLoS Genet. 2010, 6. [CrossRef]

99. Chen, C.J.; Liao, S.L. Oxidative stress involves in astrocytic alterations induced by manganese. Exp. Neurol. 2002, 175, 216-225. [CrossRef]

100. Dukhande, V.V.; Malthankar-Phatak, G.H.; Hugus, J.J.; Daniels, C.K.; Lai, J.C. Manganese-induced neurotoxicity is differentially enhanced by glutathione depletion in astrocytoma and neuroblastoma cells. Neurochem. Res. 2006, 31, 1349-1357. [CrossRef]

101. Maddirala, Y.; Tobwala, S.; Ercal, N. N-acetylcysteineamide protects against manganese-induced toxicity in SHSY5Y cell line. Brain Res. 2015, 1608, 157-166. [CrossRef]

102. Desole, M.S.; Serra, P.A.; Esposito, G.; Delogu, M.R.; Migheli, R.; Fresu, L.; Rocchitta, G.; Miele, M. Glutathione deficiency potentiates manganese-induced increases in compounds associated with high-energy phosphate degradation in discrete brain areas of young and aged rats. Aging 2000, 12, 470-477. [CrossRef] [PubMed]

103. Esterbauer, H.; Schaur, R.J.; Zollner, H. Chemistry and biochemistry of 4-hydroxynonenal, malonaldehyde and related aldehydes. Free Radic. Biol. Med. 1991, 11, 81-128. [CrossRef]

104. Aluru, N.; Karchner, S.I.; Franks, D.G.; Nacci, D.; Champlin, D.; Hahn, M.E. Targeted mutagenesis of aryl hydrocarbon receptor $2 \mathrm{a}$ and $2 \mathrm{~b}$ genes in Atlantic killifish (Fundulus heteroclitus). Aquat. Toxicol. 2015, 158, 192-201. [CrossRef] [PubMed]

105. Kadiiska, M.B.; Gladen, B.C.; Baird, D.D.; Germolec, D.; Graham, L.B.; Parker, C.E.; Nyska, A.; Wachsman, J.T.; Ames, B.N.; Basu, S.; et al. Biomarkers of oxidative stress study II: Are oxidation products of lipids, proteins, and DNA markers of CCl4 poisoning? Free Radic. Biol. Med. 2005, 38, 698-710. [CrossRef] [PubMed]

106. Milatovic, D.; Zaja-Milatovic, S.; Gupta, R.C.; Yu, Y.; Aschner, M. Oxidative damage and neurodegeneration in manganese-induced neurotoxicity. Toxicol. Appl. Pharm. 2009, 240, 219-225. [CrossRef] [PubMed]

107. Milatovic, D.; Yin, Z.; Gupta, R.C.; Sidoryk, M.; Albrecht, J.; Aschner, J.L.; Aschner, M. Manganese induces oxidative impairment in cultured rat astrocytes. Toxicol. Sci. 2007, 98, 198-205. [CrossRef] [PubMed] 
108. Zhang, J.; Perry, G.; Smith, M.A.; Robertson, D.; Olson, S.J.; Graham, D.G.; Montine, T.J. Parkinson's disease is associated with oxidative damage to cytoplasmic DNA and RNA in substantia nigra neurons. Am. J. Pathol. 1999, 154, 1423-1429. [CrossRef]

109. Isobe, C.; Abe, T.; Terayama, Y. Levels of reduced and oxidized coenzyme Q-10 and 8-hydroxy2'-deoxyguanosine in the cerebrospinal fluid of patients with living Parkinson's disease demonstrate that mitochondrial oxidative damage and/or oxidative DNA damage contributes to the neurodegenerative process. Neurosci. Lett. 2010, 469, 159-163. [CrossRef]

110. Erikson, K.M.; Aschner, M. Increased manganese uptake by primary astrocyte cultures with altered iron status is mediated primarily by divalent metal transporter. Neurotoxicology 2006, 27, 125-130. [CrossRef]

111. Huang, C.C. Parkinsonism induced by chronic manganese intoxication-an experience in Taiwan. Chang Gung Med. J. 2007, 30, 385-395.

112. Perl, D.P.; Olanow, C.W. The neuropathology of manganese-induced Parkinsonism. J. Neuropathol. Exp. Neurol. 2007, 66, 675-682. [CrossRef] [PubMed]

113. Moreno, J.A.; Streifel, K.M.; Sullivan, K.A.; Legare, M.E.; Tjalkens, R.B. Developmental exposure to manganese increases adult susceptibility to inflammatory activation of glia and neuronal protein nitration. Toxicol. Sci. 2009, 112, 405-415. [CrossRef] [PubMed]

114. Wedler, F.C.; Denman, R.B. Glutamine synthetase: The major Mn(II) enzyme in mammalian brain. Curr. Top Cell Regul. 1984, 24, 153-169. [CrossRef] [PubMed]

115. Sidoryk-Wegrzynowicz, M.; Aschner, M. Role of astrocytes in manganese mediated neurotoxicity. BMC Pharm. Toxicol. 2013, 14, 23. [CrossRef]

116. Harischandra, D.S.; Ghaisas, S.; Zenitsky, G.; Jin, H.; Kanthasamy, A.; Anantharam, V.; Kanthasamy, A.G. Manganese-Induced Neurotoxicity: New Insights Into the Triad of Protein Misfolding, Mitochondrial Impairment, and Neuroinflammation. Front. Neurosci. 2019, 13, 654. [CrossRef]

117. Olanow, C.W. Manganese-induced parkinsonism and Parkinson's disease. Ann. N. Y. Acad. Sci. 2004, 1012, 209-223. [CrossRef]

118. Moreno, J.A.; Sullivan, K.A.; Carbone, D.L.; Hanneman, W.H.; Tjalkens, R.B. Manganese potentiates nuclear factor-kappaB-dependent expression of nitric oxide synthase 2 in astrocytes by activating soluble guanylate cyclase and extracellular responsive kinase signaling pathways. J. Neurosci. Res. 2008, 86, 2028-2038. [CrossRef]

119. Sengupta, A.; Mense, S.M.; Lan, C.; Zhou, M.; Mauro, R.E.; Kellerman, L.; Bentsman, G.; Volsky, D.J.; Louis, E.D.; Graziano, J.H.; et al. Gene expression profiling of human primary astrocytes exposed to manganese chloride indicates selective effects on several functions of the cells. Neurotoxicology 2007, 28, 478-489. [CrossRef]

120. Araque, A.; Carmignoto, G.; Haydon, P.G. Dynamic signaling between astrocytes and neurons. Ann. Rev. Physiol. 2001, 63, 795-813. [CrossRef]

121. Streifel, K.M.; Moreno, J.A.; Hanneman, W.H.; Legare, M.E.; Tjalkens, R.B. Gene deletion of nos2 protects against manganese-induced neurological dysfunction in juvenile mice. Toxicol. Sci. 2012, 126, 183-192. [CrossRef]

122. Carbone, D.L.; Popichak, K.A.; Moreno, J.A.; Safe, S.; Tjalkens, R.B. Suppression of 1-methyl-4-phenyl-1,2,3,6tetrahydropyridine-induced nitric-oxide synthase 2 expression in astrocytes by a novel diindolylmethane analog protects striatal neurons against apoptosis. Mol. Pharm. 2009, 75, 35-43. [CrossRef] [PubMed]

123. Spranger, M.; Schwab, S.; Desiderato, S.; Bonmann, E.; Krieger, D.; Fandrey, J. Manganese augments nitric oxide synthesis in murine astrocytes: A new pathogenetic mechanism in manganism? Exp. Neurol. 1998, 149, 277-283. [CrossRef] [PubMed]

124. Barhoumi, R.; Faske, J.; Liu, X.; Tjalkens, R.B. Manganese potentiates lipopolysaccharide-induced expression of NOS2 in C6 glioma cells through mitochondrial-dependent activation of nuclear factor kappaB. Brain Res. Mol. Brain Res. 2004, 122, 167-179. [CrossRef] [PubMed]

125. Filipov, N.M.; Seegal, R.F.; Lawrence, D.A. Manganese potentiates in vitro production of proinflammatory cytokines and nitric oxide by microglia through a nuclear factor kappa B-dependent mechanism. Toxicol. Sci. 2005, 84, 139-148. [CrossRef] [PubMed]

126. Moreno, J.A.; Streifel, K.M.; Sullivan, K.A.; Hanneman, W.H.; Tjalkens, R.B. Manganese-induced NF-kappaB activation and nitrosative stress is decreased by estrogen in juvenile mice. Toxicol. Sci. 2011, 122, 121-133. [CrossRef] 
127. Park, E.; Chun, H.S. Melatonin Attenuates Manganese and Lipopolysaccharide-Induced Inflammatory Activation of BV2 Microglia. Neurochem. Res. 2017, 42, 656-666. [CrossRef]

128. Zhang, P.; Lokuta, K.M.; Turner, D.E.; Liu, B. Synergistic dopaminergic neurotoxicity of manganese and lipopolysaccharide: Differential involvement of microglia and astroglia. J. Neurochem. 2010, 112, 434-443. [CrossRef]

129. Crittenden, P.L.; Filipov, N.M. Manganese modulation of MAPK pathways: Effects on upstream mitogen activated protein kinase kinases and mitogen activated kinase phosphatase-1 in microglial cells. J. Appl. Toxicol. 2011, 31, 1-10. [CrossRef]

130. Dodd, C.A.; Filipov, N.M. Manganese potentiates LPS-induced heme-oxygenase 1 in microglia but not dopaminergic cells: Role in controlling microglial hydrogen peroxide and inflammatory cytokine output. Neurotoxicology 2011, 32, 683-692. [CrossRef]

131. Kim, J.; Pajarillo, E.; Rizor, A.; Son, D.S.; Lee, J.; Aschner, M.; Lee, E. LRRK2 kinase plays a critical role in manganese-induced inflammation and apoptosis in microglia. PLoS ONE 2019, 14, e0210248. [CrossRef]

132. Tran, T.T.; Chowanadisai, W.; Crinella, F.M.; Chicz-DeMet, A.; Lonnerdal, B. Effect of high dietary manganese intake of neonatal rats on tissue mineral accumulation, striatal dopamine levels, and neurodevelopmental status. Neurotoxicology 2002, 23, 635-643. [CrossRef]

133. Seth, P.K.; Chandra, S.V. Neurotransmitters and neurotransmitter receptors in developing and adult rats during manganese poisoning. Neurotoxicology 1984, 5, 67-76. [PubMed]

134. Amos-Kroohs, R.M.; Davenport, L.L.; Gutierrez, A.; Hufgard, J.R.; Vorhees, C.V.; Williams, M.T. Developmental manganese exposure in combination with developmental stress and iron deficiency: Effects on behavior and monoamines. Neurotoxicol. Teratol. 2016, 56, 55-67. [CrossRef] [PubMed]

135. Khalid, M.; Aoun, R.A.; Mathews, T.A. Altered striatal dopamine release following a sub-acute exposure to manganese. J. Neurosci. Methods 2011, 202, 182-191. [CrossRef] [PubMed]

136. Vezer, T.; Kurunczi, A.; Naray, M.; Papp, A.; Nagymajtenyi, L. Behavioral effects of subchronic inorganic manganese exposure in rats. Am. J. Ind. Med. 2007, 50, 841-852. [CrossRef] [PubMed]

137. Chen, M.K.; Lee, J.S.; McGlothan, J.L.; Furukawa, E.; Adams, R.J.; Alexander, M.; Wong, D.F.; Guilarte, T.R. Acute manganese administration alters dopamine transporter levels in the non-human primate striatum. Neurotoxicology 2006, 27, 229-236. [CrossRef]

138. Johnson, J., Jr.; Pajarillo, E.; Karki, P.; Kim, J.; Son, D.S.; Aschner, M.; Lee, E. Valproic acid attenuates manganese-induced reduction in expression of GLT-1 and GLAST with concomitant changes in murine dopaminergic neurotoxicity. Neurotoxicology 2018, 67, 112-120. [CrossRef]

139. Pajarillo, E.; Rizor, A.; Son, D.S.; Aschner, M.; Lee, E. The transcription factor REST up-regulates tyrosine hydroxylase and antiapoptotic genes and protects dopaminergic neurons against manganese toxicity. J. Biol. Chem. 2020, 295, 3040-3054. [CrossRef]

140. Pajarillo, E.; Johnson, J., Jr.; Kim, J.; Karki, P.; Son, D.S.; Aschner, M.; Lee, E. 17beta-estradiol and tamoxifen protect mice from manganese-induced dopaminergic neurotoxicity. Neurotoxicology 2018, 65, 280-288. [CrossRef]

141. Posser, T.; Franco, J.L.; Bobrovskaya, L.; Leal, R.B.; Dickson, P.W.; Dunkley, P.R. Manganese induces sustained Ser40 phosphorylation and activation of tyrosine hydroxylase in PC12 cells. J. Neurochem. 2009, 110, 848-856. [CrossRef]

142. Kawamura, M.; Sato, S.; Matsumoto, G.; Fukuda, T.; Shiba-Fukushima, K.; Noda, S.; Takanashi, M.; Mori, N.; Hattori, N. Loss of nuclear REST/NRSF in aged-dopaminergic neurons in Parkinson's disease patients. Neurosci. Lett. 2019, 699, 59-63. [CrossRef] [PubMed]

143. Lu, T.; Aron, L.; Zullo, J.; Pan, Y.; Kim, H.; Chen, Y.; Yang, T.H.; Kim, H.M.; Drake, D.; Liu, X.S.; et al. REST and stress resistance in ageing and Alzheimer's disease. Nature 2014, 507, 448-454. [CrossRef] [PubMed]

144. Zhang, D.; Kanthasamy, A.; Anantharam, V.; Kanthasamy, A. Effects of manganese on tyrosine hydroxylase (TH) activity and TH-phosphorylation in a dopaminergic neural cell line. Toxicol. Appl. Pharm. 2011, 254, 65-71. [CrossRef] [PubMed]

145. Danbolt, N.C. Glutamate uptake. Prog. Neurobiol. 2001, 65, 1-105. [CrossRef]

146. Brouillet, E.P.; Shinobu, L.; McGarvey, U.; Hochberg, F.; Beal, M.F. Manganese injection into the rat striatum produces excitotoxic lesions by impairing energy metabolism. Exp. Neurol. 1993, 120, 89-94. [CrossRef] [PubMed] 
147. Wang, L.; Fu, H.; Liu, B.; Liu, X.; Chen, W.; Yu, X. The effect of postnatal manganese exposure on the NMDA receptor signaling pathway in rat hippocampus. J. Biochem. Mol. Toxicol. 2017, 31. [CrossRef] [PubMed]

148. Ma, Z.; Liu, K.; Li, X.R.; Wang, C.; Liu, C.; Yan, D.Y.; Deng, Y.; Liu, W.; Xu, B. Alpha-synuclein is involved in manganese-induced spatial memory and synaptic plasticity impairments via TrkB/Akt/Fyn-mediated phosphorylation of NMDA receptors. Cell Death Dis. 2020, 11, 834. [CrossRef]

149. Karki, P.; Kim, C.; Smith, K.; Son, D.S.; Aschner, M.; Lee, E. Transcriptional Regulation of the Astrocytic Excitatory Amino Acid Transporter 1 (EAAT1) via NF-kappaB and Yin Yang 1 (YY1). J. Biol. Chem. 2015, 290, 23725-23737. [CrossRef]

150. Karki, P.; Webb, A.; Smith, K.; Johnson, J., Jr.; Lee, K.; Son, D.S.; Aschner, M.; Lee, E. Yin Yang 1 is a repressor of glutamate transporter EAAT2, and it mediates manganese-induced decrease of EAAT2 expression in astrocytes. Mol. Cell Biol. 2014, 34, 1280-1289. [CrossRef]

151. Eriksson, H.; Tedroff, J.; Thuomas, K.A.; Aquilonius, S.M.; Hartvig, P.; Fasth, K.J.; Bjurling, P.; Langstrom, B.; Hedstrom, K.G.; Heilbronn, E. Manganese induced brain lesions in Macaca fascicularis as revealed by positron emission tomography and magnetic resonance imaging. Arch. Toxicol. 1992, 66, 403-407. [CrossRef]

152. Bowler, R.M.; Gysens, S.; Diamond, E.; Nakagawa, S.; Drezgic, M.; Roels, H.A. Manganese exposure: Neuropsychological and neurological symptoms and effects in welders. Neurotoxicology 2006, 27, 315-326. [CrossRef] [PubMed]

153. Finkelstein, Y.; Milatovic, D.; Aschner, M. Modulation of cholinergic systems by manganese. Neurotoxicology 2007, 28, 1003-1014. [CrossRef] [PubMed]

154. Santos, D.; Milatovic, D.; Andrade, V.; Batoreu, M.C.; Aschner, M.; Marreilha dos Santos, A.P. The inhibitory effect of manganese on acetylcholinesterase activity enhances oxidative stress and neuroinflammation in the rat brain. Toxicology 2012, 292, 90-98. [CrossRef]

155. Lai, J.C.; Leung, T.K.; Lim, L. Brain regional distribution of glutamic acid decarboxylase, choline acetyltransferase, and acetylcholinesterase in the rat: Effects of chronic manganese chloride administration after two years. J. Neurochem. 1981, 36, 1443-1448. [CrossRef]

156. Lai, J.C.; Leung, T.K.; Lim, L. Differences in the neurotoxic effects of manganese during development and aging: Some observations on brain regional neurotransmitter and non-neurotransmitter metabolism in a developmental rat model of chronic manganese encephalopathy. Neurotoxicology 1984, 5, 37-47. [PubMed]

157. Eriksson, H.; Morath, C.; Heilbronn, E. Effects of manganese on the nervous system. Acta Neurol. Scand. Suppl. 1984, 100, 89-93.

158. Ye, Q.; Kim, J. Loss of hfe function reverses impaired recognition memory caused by olfactory manganese exposure in mice. Toxicol. Res. 2015, 31, 17-23. [CrossRef]

159. Wong, P.C.; Lai, J.C.; Lim, L.; Davison, A.N. Selective inhibition of L-glutamate and gammaaminobutyrate transport in nerve ending particles by aluminium, manganese, and cadmium chloride. J. Inorg. Biochem. 1981, 14, 253-260. [CrossRef]

160. Anderson, J.G.; Fordahl, S.C.; Cooney, P.T.; Weaver, T.L.; Colyer, C.L.; Erikson, K.M. Manganese exposure alters extracellular GABA, GABA receptor and transporter protein and mRNA levels in the developing rat brain. Neurotoxicology 2008, 29, 1044-1053. [CrossRef]

161. Dydak, U.; Jiang, Y.M.; Long, L.L.; Zhu, H.; Chen, J.; Li, W.M.; Edden, R.A.; Hu, S.; Fu, X.; Long, Z.; et al. In vivo measurement of brain GABA concentrations by magnetic resonance spectroscopy in smelters occupationally exposed to manganese. Environ. Health Perspect. 2011, 119, 219-224. [CrossRef]

162. Burton, N.C.; Guilarte, T.R. Manganese neurotoxicity: Lessons learned from longitudinal studies in nonhuman primates. Environ. Health Perspect 2009, 117, 325-332. [CrossRef] [PubMed]

163. Liu, G.; Aliaga, L.; Cai, H. alpha-synuclein, LRRK2 and their interplay in Parkinson's disease. Future Neurol. 2012, 7, 145-153. [CrossRef] [PubMed]

164. Bornhorst, J.; Chakraborty, S.; Meyer, S.; Lohren, H.; Brinkhaus, S.G.; Knight, A.L.; Caldwell, K.A.; Caldwell, G.A.; Karst, U.; Schwerdtle, T.; et al. The effects of pdr1, djr1.1 and pink1 loss in manganese-induced toxicity and the role of alpha-synuclein in C. elegans. Metallomics 2014, 6, 476-490. [CrossRef] [PubMed]

165. Verina, T.; Schneider, J.S.; Guilarte, T.R. Manganese exposure induces alpha-synuclein aggregation in the frontal cortex of non-human primates. Toxicol. Lett. 2013, 217, 177-183. [CrossRef]

166. Xu, B.; Wu, S.W.; Lu, C.W.; Deng, Y.; Liu, W.; Wei, Y.G.; Yang, T.Y.; Xu, Z.F. Oxidative stress involvement in manganese-induced alpha-synuclein oligomerization in organotypic brain slice cultures. Toxicology 2013, 305, 71-78. [CrossRef] 
167. Prabhakaran, K.; Chapman, G.D.; Gunasekar, P.G. alpha-Synuclein overexpression enhances manganese-induced neurotoxicity through the NF-kappaB-mediated pathway. Toxicol. Mech. Methods 2011, 21, 435-443. [CrossRef]

168. Yan, D.Y.; Liu, C.; Tan, X.; Ma, Z.; Wang, C.; Deng, Y.; Liu, W.; Xu, Z.F.; Xu, B. Mn-Induced Neurocytes Injury and Autophagy Dysfunction in Alpha-Synuclein Wild-Type and Knock-Out Mice: Highlighting the Role of Alpha-Synuclein. Neurotox. Res. 2019, 36, 66-80. [CrossRef]

169. Li, Y.; Sun, L.; Cai, T.; Zhang, Y.; Lv, S.; Wang, Y.; Ye, L. alpha-Synuclein overexpression during manganese-induced apoptosis in SH-SY5Y neuroblastoma cells. Brain Res. Bull 2010, 81, 428-433. [CrossRef]

170. Uversky, V.N.; Li, J.; Fink, A.L. Metal-triggered structural transformations, aggregation, and fibrillation of human alpha-synuclein. A possible molecular NK between Parkinson's disease and heavy metal exposure. J. Biol. Chem. 2001, 276, 44284-44296. [CrossRef]

171. Pfeffer, S.R. Two Rabs for exosome release. Nat. Cell Biol. 2010, 12, 3-4. [CrossRef]

172. Harischandra, D.S.; Ghaisas, S.; Rokad, D.; Zamanian, M.; Jin,H.; Anantharam, V.; Kimber, M.; Kanthasamy, A.; Kanthasamy, A.G. Environmental neurotoxicant manganese regulates exosome-mediated extracellular miRNAs in cell culture model of Parkinson's disease: Relevance to alpha-synuclein misfolding in metal neurotoxicity. Neurotoxicology 2018, 64, 267-277. [CrossRef] [PubMed]

173. Harischandra, D.S.; Rokad, D.; Neal, M.L.; Ghaisas, S.; Manne, S.; Sarkar, S.; Panicker, N.; Zenitsky, G.; Jin, H.; Lewis, M.; et al. Manganese promotes the aggregation and prion-like cell-to-cell exosomal transmission of alpha-synuclein. Sci. Signal 2019, 12. [CrossRef]

174. Srivastava, R.A.; Jain, J.C. Scavenger receptor class B type I expression and elemental analysis in cerebellum and parietal cortex regions of the Alzheimer's disease brain. J. Neurol. Sci. 2002, 196, 45-52. [CrossRef]

175. Tong, Y.; Yang, H.; Tian, X.; Wang, H.; Zhou, T.; Zhang, S.; Yu, J.; Zhang, T.; Fan, D.; Guo, X.; et al. High manganese, a risk for Alzheimer's disease: High manganese induces amyloid-beta related cognitive impairment. J. Alzheimers Dis. 2014, 42, 865-878. [CrossRef] [PubMed]

176. Guilarte, T.R. APLP1, Alzheimer's-like pathology and neurodegeneration in the frontal cortex of manganese-exposed non-human primates. Neurotoxicology 2010, 31, 572-574. [CrossRef]

177. Guilarte, T.R.; Burton, N.C.; Verina, T.; Prabhu, V.V.; Becker, K.G.; Syversen, T.; Schneider, J.S. Increased APLP1 expression and neurodegeneration in the frontal cortex of manganese-exposed non-human primates. J. Neurochem. 2008, 105, 1948-1959. [CrossRef]

178. Lin, G.; Li, X.; Cheng, X.; Zhao, N.; Zheng, W. Manganese Exposure Aggravates beta-Amyloid Pathology by Microglial Activation. Front. Aging Neurosci. 2020, 12, 556008. [CrossRef]

179. Moyano, P.; Garcia, J.M.; Garcia, J.; Anadon, M.J.; Naval, M.V.; Frejo, M.T.; Sola, E.; Pelayo, A.; Pino, J.D. Manganese increases Abeta and Tau protein levels through proteasome 20S and heat shock proteins 90 and 70 alteration, leading to SN56 cholinergic cell death following single and repeated treatment. Ecotoxicol. Environ. Saf. 2020, 203, 110975. [CrossRef]

180. Cai, T.; Che, H.; Yao, T.; Chen, Y.; Huang, C.; Zhang, W.; Du, K.; Zhang, J.; Cao, Y.; Chen, J.; et al. Manganese induces tau hyperphosphorylation through the activation of ERK MAPK pathway in PC12 cells. Toxicol. Sci. 2011, 119, 169-177. [CrossRef]

Publisher's Note: MDPI stays neutral with regard to jurisdictional claims in published maps and institutional affiliations.

(C) 2020 by the authors. Licensee MDPI, Basel, Switzerland. This article is an open access article distributed under the terms and conditions of the Creative Commons Attribution (CC BY) license (http://creativecommons.org/licenses/by/4.0/). 